Author: Please note that the queries that correspond to the query callouts, e.g., ?1, are on the last page of the proofs. Also note that website links were tested and confirmed during copyediting, but are not active links in page proofs. Links that break across a line will not work with Ctl+click or copy/paste. Links are made active and tested prior to posting the article to the AAA Digital Library.

Author: There are minor corrections marked. Text that appears to be struck-through will not necessarily deleted, there may be a revision marked. Please open the pop-ups to see the corrections that are marked or show the Comments list to review the correction that will be made. These will be included with your other corrections. Thank you.

\title{
Do Gender Diversity Recommendations in Corporate Governance Codes Matter? Evidence from Audit Committees
}

\author{
Nigar Sultana \\ Curtin University \\ Steven F. Cahan \\ The University of Auckland \\ Asheq Rahman \\ Auckland University of Technology
}

\begin{abstract}
SUMMARY: Motivated by two opposing views, the limited supply view and the discrimination view, we examine the impact of gender diversity guidelines on the strength of the association between the presence of female audit committee members and audit quality. The limited supply view predicts that the effect of female audit committee members on audit quality would decrease after the guidelines were issued because they increased the demand for women directors without a commensurate increase in the supply of qualified women directors. The discrimination view predicts this relation would increase after the guidelines were issued since some firms would have abandoned their suboptimal hiring practices that favored men over better qualified women, resulting in higher quality firm-director matches as opportunities for women increase. Consistent with the limited supply view, we find that the positive association between audit committee gender diversity and audit quality weakened after gender diversity guidelines were introduced in Australia.
\end{abstract}

JEL Classifications: G38; M42; M48.

Data Availability: Data are available from the databases cited in the text.

Keywords: audit committee; gender diversity; audit quality; gender diversity recommendations.

\section{INTRODUCTION}

$\mathrm{G}$ ender diversity in corporate boards continues to be a major issue for firms, the workforce, and policymakers worldwide. Between 2008 and 2015, 32 countries introduced boardroom gender diversity policies (Adams 2016). While researchers have tried to assess the impact of such policies, prior studies examining gender diversity regulations have focused on mandatory gender quotas (e.g., Ahern and Dittmar 2012; Bøhren and Staubo 2014; Eckbo, Nygaard, and Thorburn 2016; Ferreira, Ginglinger, Laguna, and Skalli 2018; Hinnerich and Jansson 2017). However, compared to mandatory quotas, gender diversity recommendations in corporate governance codes are far more common (Adams 2016). ${ }^{1}$ As corporate governance code recommendations are voluntary and are a form of "soft" regulation (Klettner,

We thank Gary S. Monroe (the editor) and three anonymous reviewers for their insights and constructive suggestions in improving the paper. We also thank Roger Simnett, Elizabeth Carson, Sarowar Hossain, Ellie Chapple, Ross Taplin, and Saurav Dutta for their valuable comments, and gratefully acknowledge the remarks from participants at the 2016 Accounting and Finance Association of Australia and New Zealand Annual Conference.

Editor's note: Accepted by Gary S. Monroe, under the Senior Editorship of Jeffrey R. Cohen.

Submitted: December 2016 Accepted: May 2019

Published Online: September 2019

\footnotetext{
1 Twenty-six of the 32 countries mentioned by Adams (2016) use guidelines in corporate governance codes. The next most common method is quotas, which are used by eight countries. Some countries use multiple methods. See Terjesen, Aguilera, and Lorenz (2015) for a discussion of how gender quotas and guidelines evolve.
} 
Clarke, and Boersma 2016), it is unclear what impact these recommendations may have on board performance. Further, prior studies have mainly examined the effect of gender diversity policies on outcomes at the firm level, such as valuation or firm performance effects. Consequently, examining how such policies affect the inner workings of the board, specifically at the subcommittee level remains an open question. ${ }^{2}$

In this study, we examine whether gender diversity recommendations in corporate governance codes have an impact on the strength of the association between the presence of female audit committee members and audit quality. We focus on the audit committee, which is the subcommittee assigned with the key responsibility of monitoring the quality of financial reporting (Australian Securities Exchange Corporate Governance Council [ASX CGC] 2010). As such, compared to the overall board that has multiple and wide-ranging functions, the audit committee has a narrow, well-defined oversight role. Thus, we are able to examine how gender diversity guidelines affect a specific corporate governance role of the board, i.e., the monitoring of financial reporting quality. We recognize that gender diversity policies do not address the audit committee explicitly. However, since board effectiveness is ultimately linked to the performance of its subcommittees (e.g., Klein 1998), understanding the flow-on effects of gender diversity policies has academic and practical significance. A few prior studies examine the effect of gender diversity on audit committee performance. ${ }^{3}$ We examine how the relation between the presence of female audit committee members and audit quality changed after a gender diversity policy was introduced.

We focus on Australia, where in 2010 corporate governance codes issued by the Australian Securities Exchange Corporate Governance Council (ASX CGC 2010; hereafter, ASX CGC 2010 guidelines) recommend, on a comply-or-explain basis, that firms establish a diversity policy, set diversity targets, and disclose information on women representation, such as the proportion of women on the board. Anecdotal evidence suggests a significant increase in gender diversity within Australian boardrooms following the introduction of the ASX CGC 2010 guidelines. In 2014, the Australian Institute of Company Directors (AICD 2014) issued a media release stating that the number of female directors increased significantly after the introduction of the 2010 guidelines (8.3 percent in 2008 to 19.2 percent in 2014). Also, in our sample, we find a significant increase in female representation on the audit committee in the post-guideline period. ${ }^{4}$ Thus, our research question is: Did the association between female representation on the audit committee and audit quality change after the introduction of the ASX CGC 2010 guidelines?

We consider two opposing views. On one hand, the guidelines may have increased the demand for qualified female directors without a commensurate increase in supply. As a result, to meet gender targets, firms may have hired less qualified women, including women with less accounting and finance experience, or women who are less committed to governance roles. If so, the relation between female representation on the audit committees and audit quality could decline in the post-guideline period. We refer to this as the limited supply view. Alternatively, some firms' hiring processes for board members before the guidelines may have been suboptimal, in particular hiring male directors when better qualified females were available. Thus, the guidelines may force these firms to abandon their suboptimal selection practices, leading to higher-quality firm-director matches as the opportunities for women improve (Ferreira, Ginglinger, Laguna, and Skalli 2018). For example, given her skill set and experience, female director A might be best matched with firm X, but because firm X discriminates, female director A's only option is on the board of firm Y. If the guidelines lead firm X to hire female directors, female director A could now be matched with firm $\mathrm{X}$ where she will be more effective. As a result, the relation between female presence on the audit committee and audit quality could increase. We refer to this as the discrimination view.

We utilize two different measures of audit quality based on prior literature (e.g., DeFond and Zhang 2014), i.e., audit fees and earnings quality. We collect data for 10,013 firm-year observations between January 2001 and December 2015, and find that, compared to the pre-ASX CGC 2010 period, the association between female audit committee members and audit quality was significantly lower after the release of the ASX CGC 2010 guidelines. Specifically, our evidence suggests that gender diversity had a greater impact on the monitoring quality of audit committees before the introduction of the ASX CGC 2010 guidelines. This is consistent with the limited supply view where the guidelines increased demand for women board members, but the supply of qualified women was limited. Our main findings are robust to a substantial number of additional analyses and after controlling for endogeneity bias.

Our study has policy and academic implications. From a policy perspective, since policymakers worldwide have mainly used "soft" regulations to promote gender diversity, whether these guidelines and recommendations are effective is a question

\footnotetext{
2 A director quoted in Lorsch and MacIver $(1989,59)$ states, "The work of the board is done in committees."

${ }^{3}$ For example, Pucheta-Martínez, Bel-Oms, and Olcina-Sempere (2016) examine the effect of female audit committee members from 2004-2011, a period prior to 2015 when the Equality Law in Spain recommended all Spanish-listed companies to have at least 40 percent women on their boards. Likewise, Srinidhi, Gul, and Tsui (2011) use U.S. data from 2001-2007 before the SEC introduced gender reporting requirements in 2010. Aldamen, Hollindale, and Ziegelmayer (2018) examine the relation between gender diversity and audit fees after the ASX in Australia introduced gender diversity recommendations in 2010, but only use data from one year, 2011.

4 See Figure 1 for year-by-year changes in female representation on audit committees for firms in our sample.
} 
that has significant policy implications going forward. Our results suggest that "soft" regulations on gender diversity can lead to changes in board composition, which can affect the inner workings of the board. Thus, voluntary guidelines can motivate firms to change their behavior by putting pressure on firms and making their nonconformance more visible. In the post-ASX CGC 2010 period, we find evidence consistent with an unintended consequence of the policy; that is, in order to comply with the guidelines, it appears firms appointed less qualified women to the audit committee. However, we acknowledge that we only examine one subcommittee, and it is possible the effect of gender diversity on other subcommittees and board functions could differ. Thus, we acknowledge that our study does not—and is not intended to—provide a full assessment of the effectiveness of the gender diversity guidelines by the ASX CGC (2010).

From an academic perspective, we extend the prior literature on the effect of gender diversity on audit committees (Aldamen et al. 2018; Ittonen, Miettinen, and Vahamaa 2010; Pucheta-Martinez et al. 2016; Srinidhi et al. 2011; Sun, Liu, and Lan 2011; Thiruvadi and Huang 2011) by conducting difference-in-differences tests around an exogenous shock related to the introduction of a gender diversity policy. Further, we add to the broader literature in finance and economics that examines the impact of national policies on gender diversity (e.g., Ahern and Dittmar 2012; Bøhren and Staubo 2014; Eckbo et al. 2016; Ferreira et al. 2018; Hinnerich and Jansson 2017) by examining voluntary guidelines rather than mandatory quotas and by considering the effect of the policy on a specific board function-monitoring financial reporting quality.

The remainder of this paper is structured as follows. Section II reviews the related literature and develops our hypotheses. Section III discusses the research method. Section IV contains results, and Section V is our summary and conclusion.

\section{LITERATURE REVIEW AND HYPOTHESIS}

\section{Gender Diversity Regulations}

Gender diversity regulations can be viewed as an exogenous shock that affects the demand for female directors (e.g., Ferreira et al. 2018). There are two opposing views on how such a shock might affect the association between female representation on the board (subcommittees) and the performance of the board (subcommittees). First, pressuring firms to increase female representation on the board could lead to lower board performance if firms have to retain less qualified female directors. This view assumes that boards were composed optimally before the shock and that women would have been hired as directors if they were more qualified than men. If the supply of qualified women is limited, to meet gender-based targets in the post-guideline period, firms would have to hire women who are less qualified than their male counterparts, resulting in lower board performance. To the extent that some of these new women board members also serve on subcommittees, subcommittee performance could also suffer. We refer to this explanation as the limited supply view.

Second, it is possible that the low levels of women representation on boards and subcommittees reflect discriminatory hiring practices where less qualified men are hired instead of better qualified women. To the extent that the introduction of gender diversity policies force firms to abandon suboptimal hiring (i.e., discriminatory) practices, board performance could increase as firms hire better qualified women directors who were previously overlooked. By creating more opportunities for

?1 women directors and reducing frictions in the labor market, the quality of firm-director matches is likely to improve. ${ }^{5}$ For example, with more options available as discriminatory practices decline, qualified women directors can cherry pick the board assignments that best fit their ability and tastes (Ferreira et al. 2018). We refer to this explanation as the discrimination view.

As Ferreira et al. (2018) note, such discrimination is not necessarily intentional and could, in fact, be rational. For example, it may be less costly to evaluate candidates who come from a similar background (e.g., an "old boy network"). However, by increasing the costs associated with such practices (e.g., increased social pressure on the firm or penalties if there is a mandatory quota), gender diversity guidelines can change this cost equation, leading to more equitable hiring practices.

Most of the prior research on gender diversity regulations examine gender quotas, a "hard" regulation, and their effect at the board level. Several of these studies focus on Norway where a law passed in 2003 required that boards consist of at least 40 percent female directors and 40 percent male directors from 2008. Ahern and Dittmar (2012) find that increase in women directors in listed Norwegian firms had a negative effect on firm value. Bøhren and Staubo (2014) find that 51 percent of the listed Norwegian firms that were potentially affected by the law voluntarily changed their organizational form (became unlisted) so they could avoid the law, indicating that, for these firms, the expected costs of the quota outweighed the expected benefit. Moreover, those firms that did comply with the law, and increased female representation, experienced significantly lower growth compared to the firms that did not comply. However, Eckbo et al. (2016) find evidence that the Norwegian law was value-neutral after correcting for econometric issues.

\footnotetext{
5 Ferreira et al. (2018) explain that better firm-director matching can occur "if, before the quota, some firms considered a restricted set of qualified women as potential candidates. If the quota forces firms to change hiring practices, firms may now find even better female candidates, thus improving [firm-director] match quality."
} 
Hinnerich and Jansson (2017) argue that prior studies have not fully incorporated an anticipation effect, where firms increase female representation in anticipation of new gender diversity regulations. In their setting, they identify a credible threat that a quota law would be introduced in Sweden. Specifically, Margareta Winberg, who had been a long-time advocate of gender quotas, was appointed as the minister of gender equality in 2002, significantly raising the likelihood that a law would be enacted in Sweden. Hinnerich and Jansson (2017) find that after Winberg's appointment, there was an increase in the proportion of female board members and an associated increase in firm performance, consistent with the anticipated quota law having a positive effect on Swedish firms. ${ }^{6}$

Ferreira et al. (2018) examine the introduction of a mandatory gender quota in France in 2011 by computing turnover rates for female directors. They find that the turnover rate for female directors fell by a third after the law was enacted, consistent with better matches between firms and female directors. They argue that their results are consistent with the quota law forcing firms to abandon discriminatory selection practices, leading to the hiring of under-recruited qualified women, or with the law increasing the cost of hiring qualified women because of increased competition. Their findings are consistent with the mandatory gender quota in France improving the quality of firm-director matches. Thus, they conclude that the quota law improved the functioning of the labor market for directors.

Overall, the results of studies examining the efficacy of mandatory quota laws, as discussed above, are mixed, with studies finding positive and negative support for females on the board. A possible reason for the mixed findings is that the prior studies focus on the effect of mandatory quota laws on broad outcomes such as firm value or performance, turnover of female directors, and organizational form that are likely to be affected by a wide range of other factors. By focusing on the audit committee, which has a clear role and function, and a specific outcome, audit quality, we can examine the effects of female directors in a more well-defined space.

Further, instead of examining quota laws, we examine gender diversity recommendations in corporate governance codes, which are far more common than quota laws (e.g., Adams 2016). Corporate governance code recommendations are a form of "soft" regulation since they are voluntary (e.g., Klettner et al. 2016). Chow and Wong-Boren (1987) and Khurana and Raman (2004) demonstrate that voluntary settings better expose the effects of managerial decisions. Still, the ramifications of soft regulations are not obvious. On one hand, the voluntary aspect of these codes may magnify firms' responses since those with the most (least) benefit will follow (ignore) the recommendation, amplifying the differences between the firms that increase female representation and those that do not. On the other hand, these guidelines may function as de facto laws if firms face pressure from investors, customers, competitors, regulators, the media, and society to conform (e.g., Klettner et al. 2016). ${ }^{7}$ In any case, more research on the efficacy of these "soft" regulations is needed. For instance, the Organisation for Economic Cooperation and Development (OECD 2004, 52) states that "Although voluntary codes and principles have the advantage of maintaining flexibility and avoiding excessive and costly legal and regulatory measures, the question of their effectiveness does arise."

Finally, we note that the impact of gender diversity policies can be evaluated from different perspectives. For example, some researchers, using a moral justice perspective, argue that there is an ethical case for having greater female representation on boards to represent a fairer gender balance and provide equal opportunity (Ben-Amar, Chang, and McIlkenny 2017; Terjesen, Sealy, and Singh 2009). Thus, the ethical case uses a different yardstick to measure the success of gender diversity policies, i.e., an increase in female representation may be sufficient to indicate that the policy is a success. In this study, we focus on the effect of gender diversity on an economic outcome (audit quality), but we recognize that there may be other noneconomic metrics that could be used to assess the impact of the guidelines.

\section{Audit Committee Gender Diversity and Audit Quality}

We focus on audit committees because they play a crucial role in financial reporting (Gendron and Bedard 2006). The typical responsibilities of the audit committee include oversight of (1) the quality and integrity of the financial reports, which include monitoring the choice of accounting policies and principles, (2) compliance with legal and regulatory requirements, (3) the external auditor's qualifications and independence, and (4) risk management and the performance of the internal audit function. In fulfilling their obligations, audit committee members are expected to communicate with the firm's external auditor to ensure that the quality of the external audit is maintained. For example, audit committee members are expected to meet regularly with their external auditor to review the audit scope, audit programs, and resulting audit findings (Australian Securities \& Investments Commission 2014; Trotman, Bauer, and Humphreys 2015).

\footnotetext{
${ }^{6}$ In our setting, the very low female representation in audit committees prior to the issuing of the ASX CGC 2010 guidelines (e.g., see Table 2, Panel C) suggests that firms did not increase gender diversity in anticipation of the guidelines.

7 Chapple and Humphrey (2014) argue that Australia's voluntary gender quota system imposes strong external pressure on Australian firms to appoint female board members.
} 
The audit committee's responsibility can also extend to monitoring real earnings management. C. Laux and V. Laux (2009) note that the audit committee monitors the integrity of the firm's financial statements and the performance of the internal ?2 audit function. They state that "the task of the audit committee is to oversee the financial reporting process in order to reduce the magnitude of earnings management" (Laux and Laux 2009, 873), and as a result, an attentive audit committee "should be better able to restrict management from undertaking or continuing real activities that are aimed at manipulating the report" (Laux and Laux 2009, 874; emphasis added). Further, because real earnings management is activities based rather than accounting policies based, it is less likely to be scrutinized by auditors than accrual-based earnings management. Likewise, Graham, Harvey, and Rajgopal (2005) report that managers frequently engage in real earnings management, and Cohen, Dey, and Lys (2008) find real earnings management has become a more common tool for earnings management as managers shift away from accruals-based earnings management, which is more visible, suggesting that audit committees are increasingly likely to monitor real earnings management more closely.

A discussion of the effect of audit committees on audit quality and fees is complicated by different theoretical perspectives regarding the audit committee's corporate governance role (Carcello, Hermanson, and Ye 2011; DeFond and Zhang 2014; Hay, Knechel, and Wong 2006; Knechel and Willekens 2006). On one hand, an effective audit committee may complement the audit function. Using this view, the presence of an effective audit committee may result in higher audit fees and audit quality as audit committee members demand more auditing to fulfill their oversight responsibilities and protect their personal reputation from damage if management commits fraud (Knechel and Willekens 2006). Similarly, auditors may exert more effort (e.g., do more substantive testing), resulting in higher fees, if they believe more effective audit committees have higher standards.

On the other hand, an active audit committee may also substitute for the audit function. If so, an effective audit committee may demand less audit services or, alternatively, an auditor may supply less audit services in the presence of an effective audit committee because the auditor assesses a lower risk (Carcello et al. 2011; Krishnan and Visvanathan 2009). For example, an audit committee's role in strengthening the internal control structure may lead the external auditor to rely more on the internal controls, resulting in less substantive testing and lower audit fees. Thus, the audit committee can have a complementary or substitutive corporate governance role.

Although a few studies support the substitutive view (Chan, Liu, and Sun 2013; Krishnan and Visvanathan 2009), the case is stronger for the complementary view. For example, with regard to audit committees, Abbott, Parker, Peters, and Raghunandan (2003) find that audit committee independence and financial expertise are significantly and positively associated with audit fees. Vafeas and Waegelein (2007) document a positive association between audit committee size, independence, and financial expertise with audit fees. Also, Goodwin-Stewart and Kent (2006) document that the existence of an audit committee and more frequent audit committee meetings are associated with higher audit fees in Australia. In relation to real earnings management, Sun, Lan, and Liu (2014) show that additional directorships by audit committee members are positively associated with real earnings management.

Only a few studies consider the impact of audit committee gender diversity on financial reporting and auditing, and almost all of these studies use data from periods before gender diversity policies were put in place. Srinidhi et al. (2011) examine the relation between board and audit committee gender diversity and earnings quality using a U.S.-based sample of 2,480 firm-year observations over the period 2001-2007. They report that firms with at least one female audit committee member exhibit higher earnings quality, which they measure using both accruals quality and meeting/beating an earnings benchmark. Thiruvadi and Huang (2011) use a U.S. sample of 320 firms from the Standard \& Poor's Small Cap 600 firms in 2003 and document evidence that the presence of female directors on the audit committee reduces earnings management (measured by abnormal discretionary accruals). Using a sample of 920 firm-year observations from Spain, Pucheta-Martinez et al. (2016) find that female directors on the audit committee improve the quality of financial information measured by the issuance of a qualified audit report. However, Sun et al. (2011) fail to find any association between audit committee gender diversity and earnings management (measured by discretionary accruals) using a sample of 525 U.S. firm-year observations for the period $2003-2005$.

Regarding the relation between gender diversity and audit fees, Ittonen et al. (2010) use a U.S. sample of 941 firm-year observations from 2006-2008 and find that gender diversity on audit committees is negatively associated with audit fees. Using Australian data of 624 firms from 2011, Aldamen et al. (2018) find that having a female on the audit committee is positively related to audit fees. ${ }^{8}$ Overall, the research on audit committee gender diversity suggests that greater female representation on this subcommittee does affect audit quality.

\footnotetext{
${ }^{8}$ In a separate line of research, prior studies suggest that auditor partner gender can have a differing impact on the financial reporting process. For example, Hossain, Chapple, and Monroe (2018) find that female audit partners are less likely to issue going concern opinions for financially distressed firms, suggesting that gender differences among audit partners influence audit reporting decisions. Hardies, Breesch, and Branson (2015) examine whether audit fees are higher for female audit partners compared to males and find that there is a female audit fee premium of about 7 percent. Similarly, Ittonen, E. Vahamaa, and S. Vahamaa (2013) investigate the association between accruals quality and audit partner gender and document that firms with female audit partners have higher accruals quality.
} 
Our study differs from this line of research as our purpose is to examine how the introduction of gender diversity guidelines altered the relation between audit committee gender diversity and audit quality. As discussed, there are two views regarding the implications of gender diversity policies: the limited supply view and discrimination view. In our context, the limited supply view suggests that the relation between female representation on the audit committee and audit quality will be negatively affected by the gender diversity guidelines as firms hire less qualified women directors to meet their gender-based targets. In contrast, the discrimination view suggests that the relation between female representation on the audit committee and audit quality will become more positive after the introduction of the guidelines since the quality of firm-director matches improves as firms hire highly qualified women directors who were previously overlooked because of suboptimal hiring practices. Whether the limited supply or discrimination view prevails is an empirical question. Consequently, we examine the following nondirectional hypothesis (in alternative form):

H1: The association between female representation on the audit committee and audit quality is different in the post-ASX CGC 2010 period compared to the pre-ASX CGC 2010 period.

\section{RESEARCH DESIGN}

\section{Sample Selection and Source Documentation}

Our initial sample comprises all firms listed on the ASX from 2001-2015. Consistent with prior research (Abbott et al. 2003; Blankley, Hurtt, and MacGregor 2012; Carcello, Hermanson, Neal, and Riley 2002), we exclude financial (3,351), insurance (143), utility (412), and trust (691) firm-years because of their different regulatory requirements in which the standard audit fee determinants model is not applicable. We also exclude 1,543 IPO firm-years consistent with prior research (Abbott et al. 2003). Foreign incorporated and domiciled firm-years (2,527) are also excluded since financial statements of these entities are not necessarily prepared in accordance with the typical disclosure requirements of Australian ASX listed, incorporated, and domiciled firms (Clifford and Evans 1997). We also exclude firms without audit committees (i.e., 3,752 firm-years). After making these exclusions, our usable population starts with 14,590 firm-year observations. Finally, missing corporate governance, financial, and audit and nonaudit fee data reduce our sample to 10,013 firm-year observations. Panel A of Table 1 provides a summary of the sample selection process, while Panel B presents an industry breakdown (by firm-year observations) ?3 of the final sample. ${ }^{9}$

Data to calculate the variables of interest were obtained from a number of sources. Audit and nonaudit fees data, including the majority of control variables, were obtained from the Aspect Huntley's financial database (specifically, FinAnalysis and/or DatAnalysis), Capital IQ, OSIRIS, and Orbis. Corporate governance variables were collected from the SIRCA Corporate Governance, Capital IQ, and Connect4 databases. Finally, data not available from databases were hand collected from the financial year-end annual reports obtained from the Connect 4 Annual Reports Collection. This information included the gender of board and audit committee members.

\section{Measurement of Variables}

\section{Audit Quality}

Our measures for audit quality are derived from two key monitoring functions of the audit committee: (1) external monitoring (i.e., engagement, compensation, and quality of the external auditor), and (2) internal monitoring, (i.e., monitoring financial reporting quality). For external monitoring, we use audit fees as a proxy, while earnings quality is our measure for internal monitoring. Unlike prior studies, we use an earnings quality measure based on real earnings management. We use real earnings management because we want to isolate the audit committee's internal governance role. Because accruals are within the purview of both the auditor and audit committee, it is not possible to determine the degree to which the audit committee affects accruals-based earnings management. In contrast, auditors have less interest in real

\footnotetext{
9 In order to check the representativeness of our sample, we undertake a number of additional analyses. First, we perform independent sample t-tests for both corporate governance and firm characteristics for two sample groups: (1) firms used in our paper, and (2) firms that had missing data. Results suggest that the means of the variables used are not significantly different between these two sample groups. Second, with regard to the missing data on the audit fees and governance variables, we ran an analysis to generate the predicted value of each of the missing variables and re-run our analysis using these predicted values instead of the actual values. Our results continue to be significant. Third, we perform analyses where we run individual regressions between each of the governance and firm characteristics used in the paper (being the dependent variable in the regression) and a new variable (where a score of 1 is given to a firm if there are missing data, 0 otherwise) as the independent variable. Results suggest that there is no significant association indicating that the variables/characteristics of the excluded firms are not dissimilar to variables of the firms included in our sample. Overall, the results of these analyses suggest our sample is representative of the broader population.
} 
TABLE 1

\section{Panel A: Sample Selection}

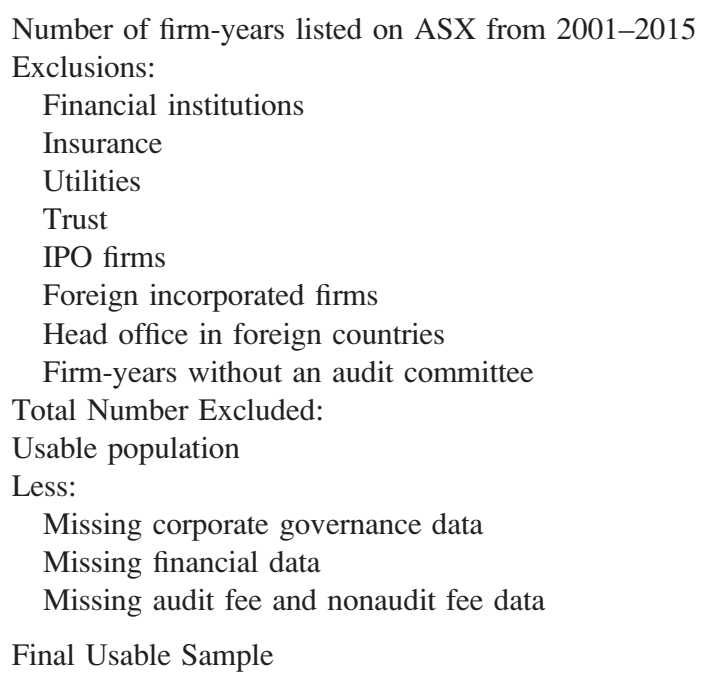

Panel B: By Industry

\begin{tabular}{l} 
ASX Industry \\
\hline Consumer Discretionary \\
Consumer Staples \\
Energy \\
Health Care \\
Industrials \\
Information Technology \\
Materials \\
Telecommunication Services \\
Total
\end{tabular}

\begin{tabular}{crrr}
$\begin{array}{c}\text { No. Firm-Year } \\
\text { Observations }\end{array}$ & & Percent \\
\cline { 1 - 1 } 1,439 & & 14.37 \\
476 & & 4.75 \\
842 & & 8.41 \\
958 & & 9.57 \\
1,617 & & 16.15 \\
774 & & 7.73 \\
3,670 & & 36.65 \\
237 & & 2.37 \\
\hline 10,013 & & 100
\end{tabular}

Table 1 presents details about the sample selection.

earnings management (e.g., Cohen et al. 2008), leaving the audit committee to be the primary monitor of such activity. As part of the audit committee's oversight responsibility over financial reporting and disclosures, audit committee members review management's accounting choices and decisions. For example, when audit committee members observe any abnormal changes in revenue and expense items, they should discuss such issues and related business operations with management. This aspect of the audit committee's duty was strengthened by regulations like ASX CGC (2010) and the Sarbanes-Oxley Act (U.S. House of Representatives 2002), which require the audit committee to have a thorough understanding of business operations and relevant accounting choices.

Audit fee. Consistent with past literature (Abbott et al. 2003; Blankley et al. 2012; Carcello et al. 2002; Hay et al. 2006), we measure audit fees as the natural logarithm of audit fees paid by firm $i$ for audit services in time period $t$ ( Ln_AudFee).

Earnings quality. Our proxy for earnings quality is real earnings management. We use the real earnings management model developed by Roychowdhury (2006). In line with Roychowdhury (2006), we compute the abnormal levels of cash flow from operations, production cost, and discretionary expenses to study the level of real activities management undertaken by the firm. First, we calculate the normal levels of cash flow from operations, production cost, and discretionary expenses consistent with Roychowdhury (2006). To generate abnormal cash flows, we run the following cross-sectional regression for each industry and year: 


$$
\text { CFO } / \text { TA }-1=\beta_{0}+\beta_{1}\left(1 / T A_{-1}\right)+\beta_{2}\left(\text { Sales } / T A_{-1}\right)+\beta_{3}\left(\Delta \text { Sales } / T A_{-1}\right)+\varepsilon
$$

where $C F O$ is cash flow from operations, $T A_{-1}$ is the dollar value of total assets in year $t-1$, and Sales is sales revenue.

We estimate the abnormal production expenses model from the following regression:

$$
\text { PROD } / \text { TA }_{-1}=\beta_{0}+\beta_{1}\left(1 / \text { TA }_{-1}\right)+\beta_{2}(\text { Sales } / \text { TA }-1)+\beta_{3}\left(\Delta \text { Sales } / \text { TA } A_{-1}\right)+\beta_{4}\left(\Delta \text { Sales }_{-1} / \text { TA }_{-1}\right)+\varepsilon
$$

where $P R O D$ is the sum of the cost of goods sold and change in inventory.

Last, we calculate abnormal discretionary expenses as follows:

$$
\text { DISX } / \text { TA }_{-1}=\beta_{0}+\beta_{1}\left(1 / \text { TA }_{-1}\right)+\beta_{2}\left(\text { Sales }_{-1} / \text { TA }_{-1}\right)+\varepsilon
$$

where DISX is discretionary expenses.

The residuals obtained from Equations (1) to (3), estimated by industry and year, represent the abnormal cash flows $\left(C F O \_R\right)$, abnormal production cost $\left(P R O D_{-} R\right)$, and abnormal discretionary expenses $\left(D I S X \_R\right)$, respectively, where these three variables are proxies for real earnings management. As mentioned in Cohen et al. (2008), firms that manage earnings upward are likely to have one or more of the following: abnormally low cash flows from operations, abnormally low discretionary expenses, and abnormally high production costs. In order to capture the impact of real earnings management through these three variables comprehensively, we compute a single variable by combining the three individual real earnings management variables (Cohen et al. 2008). Specifically, we generate Comp_REM as the sum of standardized variables, $C F O \_R, P R O D \_R$, and $D I S X \_R$. Note that Comp_REM is an inverse measure of earnings quality, i.e., higher values indicate greater real earnings management and lower earnings quality.

\section{Audit Committee Gender Diversity}

We measure gender diversity on the audit committee in three different ways: (1) a continuous measure (\%ACFemale), (2) a dichotomous measure (DumACFemale), and (3) the actual number of female audit committee members (\#ACFemale). The continuous measure is the ratio of the total number of female audit committee members to audit committee size. The dichotomous measure is coded 1 for firms with female audit committee members, and 0 otherwise. We also incorporate a number of additional measures of gender diversity in our supplementary tests that capture the addition, replacement, and increase of female directors on the audit committee.

\section{Control Variables}

With regard to the audit fee model, consistent with past literature, we control for audit fee determinants associated with client size, risk, complexity, and other governance attributes (e.g., Hay et al. 2006). Specifically, we control for client size and complexity (larger firm, greater number of subsidiaries, higher market-to-book ratio, greater number of business segments and geographical segments), financial risk (higher leverage, lower return on assets), and higher inherent risk (i.e., a larger amount of inventory and receivables). A number of auditor-related characteristics are also found to be associated with audit quality such as Big 4, tenure, industry specialization, audit partner gender, and nonaudit fees. (Balsam, Krishnan, and Yang 2003; Hardies et al. 2015; Hossain et al. 2018; Ittonen et al. 2013; Mansi, Maxwell, and Miller 2004; Read and Yezegel 2016). Consequently, we control for such characteristics. Prior research has also documented an association between board and audit committee characteristics and audit fees. Consistent with Carcello et al. (2002) and Abbott et al. (2003), we control for board size, board independence, CEO duality, audit committee size, independence, financial expertise, and meeting frequency. We also control for other audit committee variables that may affect audit fees; namely, the average of audit committee members' tenure and multiple directorships. Definitions of all variables are provided in Appendix A.

In regard to the real earnings management model, we include a proxy for firm size as a control variable because prior research suggests that the smaller firms may have high earnings management (Barua, Legoria, and Moffitt 2006; Dechow and Dichev 2002). Further, revenue volatility and cash flows volatility are included because greater fluctuations in revenues and cash flows can influence the accruals significantly (Francis, Huang, Rajgopal, and Zang 2008). Prior research suggests a positive relation between firm growth and earnings management (Barua et al. 2006; Klein 2002), and to control for the prior and future growth of the firm, a market-to-book ratio is included. Research suggests that accruals are higher for firms with poor performance (Barua et al. 2006; Dechow and Dichev 2002), therefore we include return on assets to control for the performance of the firm. Further, we also control for loss and leverage (e.g., Cohen and Zarowin 2010). In addition to firm characteristics, a number of corporate governance variables are also included in the regression including Big 4, CEO duality, board size, percentage of independent board of directors, audit committee size, audit committee meeting frequency, percentage of independent audit committee members, percentage of audit committee members with financial expertise, and the average of audit committee members' tenure and multiple directorships. 


\section{Regression Models}

To set a baseline for our tests of H1, we first estimate the relation between audit committee gender diversity and audit quality measured by audit fees and real earnings management:

$$
\begin{aligned}
& \text { Ln_AudFee }=\beta_{0}+\beta_{1} \text { ACGenderDiversity }+ \text { Controls }+\varepsilon \\
& \text { Comp_REM }=\beta_{0}+\beta_{1} \text { ACGenderDiversity }+ \text { Controls }+\varepsilon
\end{aligned}
$$

where ACGenderDiversity is either \%ACFemale, DumACFemale, or \#ACFemale, the controls are as described above, and firm and year fixed effects are included. Based on prior research, $\beta_{1}$ is predicted to be positive (negative) in Equation (4) (Equation (5)) and consistent if the audit committee has a complementary corporate governance role.

To test $\mathrm{H} 1$, we include POST, an indicator variable equal to 1 for firm-year observations after 2010 when the ASX CGC guidelines were introduced, and we interact POST with our measures of audit committee gender diversity:

$$
\begin{aligned}
& \text { Ln_AudFee }=\beta_{0}+\beta_{1} \text { ACGenderDiversity }+\beta_{2} \text { POST }+\beta_{3} \text { ACGenderDiversity } * \text { POST }+ \text { Controls }+\varepsilon \\
& \text { Comp_REM }=\beta_{0}+\beta_{1} \text { ACGenderDiversity }+\beta_{2} \text { POST }+\beta_{3} \text { ACGenderDiversity } * \text { POST }+ \text { Controls }+\varepsilon
\end{aligned}
$$

where $\beta_{3}$ is the coefficient of interest in each equation. In Equation (6), we expect that $\beta_{3}$ will be negative (positive) if the limited supply (discrimination) view is supported. In Equation (7), we expect that $\beta_{3}$ will be positive (negative) if the limited supply (discrimination) view is supported. We estimate Equations (4)-(7) with firm fixed effects included. ${ }^{10}$

\section{EMPIRICAL RESULTS}

\section{Descriptive Statistics and Correlations}

Panel A of Table 2 provides descriptive statistics for the variables used to estimate Equations (4) to (7). ${ }^{11}$ The mean of $L n$ AudFee is 11.676 , indicating that the mean audit fee paid by the firms in our sample is $\$ 472,165$. In terms of real earnings management values, the average of $C F O \_R, P R O D \_R$, and $D I S X \_R$ are $-0.009,-0.032$, and -0.207 , respectively. The average audit committee has 3.3 members. With respect to audit committee gender diversity, on average, 6.9 percent of audit committee members are female, and 24.5 percent of the sample has at least one female on the audit committee. On average, 56.3 percent of the audit committee members are independent directors, and 28.1 percent of audit committee members have financial expertise. The average number of audit committee meetings in a year is 3.2.

Panel B of Table 2 provides further descriptive statistics for the audit committee highlighting several differences between male and female members. Specifically, using firm-level information, Panel B of Table 2 suggests that female audit committee members have, on average, greater levels of independence, financial expertise (marginally), additional directorships, and attend more audit committee meetings than male audit committee members. Female members also tend to have much shorter tenure on the audit committee. ${ }^{12}$

Panel C of Table 2 provides tests of differences for the audit committee gender diversity variables in the pre- and post-ASX CGC 2010 periods. Using firm-level information, all measures are significantly higher in the post-ASX CGC 2010 period, consistent with anecdotal evidence reported earlier in the paper that the introduction of the guidelines is associated with an increase in female representation on boards in Australia. Findings illustrated in Figure 1 further highlight that there was a significant increase of female representation on the audit committees post-ASX CGC 2010. Whether this increase is associated with greater or less monitoring of auditing and financial reporting is addressed in our multivariate analysis.

\section{Main Results}

Table 3 provides the baseline results where we estimate the unconditional relation between audit committee gender diversity and audit quality. ${ }^{13}$ Column 1 of Table 3 presents the regression using the proportion of female audit committee members (\%ACFemale). Columns 2 and 3 provide results using the dichotomous measure (DumACFemale) and the number of female audit

\footnotetext{
10 Since POST is a linear combination of year fixed effects, these are suppressed when POST is included.

11 All continuous variables (except log transformed variables) are winsorized at 1 percent and 99 percent.

12 We conduct additional descriptive analyses using individual director-level data. Specifically, we have 7,343 unique individual directors on audit committees during our sample period, of which 519 are female. The results (untabulated) relating to differences between male and female members are consistent with the descriptive analyses based on the firm-level data reported in Panel B of Table 2.

13 Table 3 reports coefficient estimates and White-Huber t-statistics clustered at the firm level. Standard errors of these regressions are clustered by firms to mitigate serial correlation arising from our multiple-year observations.
} 
TABLE 2

Descriptive Statistics

Panel A: Descriptive Statistics for Full Sample

\begin{tabular}{|c|c|}
\hline Variable & Mean \\
\hline Ln AudFee & 11.676 \\
\hline$C \overline{F O}{ }_{-}$ & -0.009 \\
\hline PROD_R & -0.032 \\
\hline$D I S X \_\bar{R}$ & -0.207 \\
\hline$\% A C \bar{F}$ emale & 0.069 \\
\hline DumACFemale & 0.245 \\
\hline \#ACFemale & 0.233 \\
\hline$\% A C I n d$ & 0.563 \\
\hline ACSize & 3.313 \\
\hline ACMeet & 3.199 \\
\hline$\% A C F i n$ & 0.281 \\
\hline ACTenure & 7.634 \\
\hline ACMul & 1.592 \\
\hline Duality & 0.081 \\
\hline BSize & 6.329 \\
\hline BoDInd & 0.402 \\
\hline Ln_NAS & 7.236 \\
\hline Big4 & 0.543 \\
\hline Aud_Gender & 0.089 \\
\hline Aud_Ind-Specialist & 0.190 \\
\hline Aud_Tenure & 7.130 \\
\hline Ln_TA & 16.241 \\
\hline$R O A$ & -0.080 \\
\hline$M B$ & 2.151 \\
\hline Leverage & 1.681 \\
\hline $\operatorname{Inv} \operatorname{Rec}$ & 0.080 \\
\hline Sub & 31.071 \\
\hline Bus_Seg & 1.578 \\
\hline Geo_Seg & 1.354 \\
\hline Loss & 0.389 \\
\hline $\mathrm{CFO}_{-} \mathrm{Vol}$ & 4.153 \\
\hline Rev_Vol & 5.997 \\
\hline
\end{tabular}

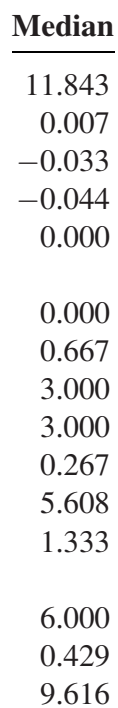

6.000

18.107

0.017

1.240

1.419

0.043

13.000

1.000

1.000

4.000

6.211

\begin{tabular}{l} 
SD \\
\hline 1.468 \\
0.292 \\
0.456 \\
0.772 \\
0.135 \\
\\
0.509 \\
0.388 \\
1.160 \\
1.780 \\
0.275 \\
5.531 \\
1.475 \\
\\
2.287 \\
0.284 \\
5.408
\end{tabular}

5.663

6.682

0.439

3.294

1.725

0.092

44.919

2.013

1.805

1.236

1.477
Min.

\subsection{5}

$-1.553$

$-1.922$

$-3.040$

0.000

0.000

0.000

1.000

1.000

0.000

1.041

0.000

2

0.000

0.000

0.000

0.000

$-3.833$

$-6.020$

$-2.773$

0.000

0.000

0.000

0.000

1.149

2.237
Max.

16.307

1.342

1.929

2.698

1.000

4.000

1.000

11.000

9.000

1.000

12.954

6.000

13

1.000

15.125

19.000

24.677

0.378

22.310

11.648

0.363

195.000

8.000

8.000

7.012

10.589

Panel B: Descriptive Statistics for Audit Committee by Gender

\begin{tabular}{l} 
Variable \\
\hline \%ACInd (Male) \\
\%ACInd (Female) \\
ACMeet (Male) \\
ACMeet (Female) \\
\%ACFin (Male) \\
\%ACFin (Female) \\
ACTenure (Male) \\
ACTenure (Female) \\
ACMul (Male) \\
ACMul (Female)
\end{tabular}

$$
\begin{aligned}
& \text { Mean } \\
& \hline 0.530 \\
& 0.746 \\
& 2.865 \\
& 3.830 \\
& 0.392 \\
& 0.402 \\
& 8.648 \\
& 2.873 \\
& 1.494 \\
& 1.870
\end{aligned}
$$

$$
\begin{gathered}
\text { Median } \\
\hline 0.600 \\
1.000 \\
2.333 \\
4.000 \\
0.333 \\
0.000 \\
6.002 \\
3.266 \\
1.250 \\
2.000
\end{gathered}
$$

$\frac{\text { SD }}{0.390}$
0.429
1.528
1.898
0.319
0.468
6.758
2.779
1.410
1.642

\begin{tabular}{lr}
$\frac{\text { Min. }}{0.000}$ & Max. \\
0.000 & 1.000 \\
1.000 & 1.000 \\
1.000 & 8.000 \\
0.000 & 9.000 \\
0.000 & 1.000 \\
1.008 & 1.000 \\
0.071 & 16.983 \\
0.000 & 6.896 \\
0.000 & 6.000 \\
\multicolumn{2}{c}{ (continued on next page) }
\end{tabular}


TABLE 2 (continued)

Panel C: Test of Differences between Means

\begin{tabular}{|c|c|c|c|c|c|c|c|}
\hline \multirow[b]{2}{*}{ Variable } & \multicolumn{3}{|c|}{ Pre-ASX CGC 2010} & \multicolumn{3}{|c|}{ Post-ASX CGC 2010} & \multirow{2}{*}{$\begin{array}{l}\text { Test of Diff. } \\
\text { (p-value) }\end{array}$} \\
\hline & Mean & Median & SD & Mean & Median & SD & \\
\hline$\%$ ACFemale & 0.045 & 0.000 & 0.104 & 0.080 & 0.000 & 0.145 & 0.000 \\
\hline DumACFemale & 0.117 & 0.001 & 0.121 & 0.223 & 0.000 & 0.211 & 0.000 \\
\hline \#ACFemale & 0.156 & 0.000 & 0.182 & 0.274 & 0.000 & 0.359 & 0.000 \\
\hline
\end{tabular}

Table 2 presents descriptive statistics for all variables included in the analyses. Specifically, Panel A of Table 2 provides descriptive statistics for all variables used to estimate Equations (4)-(7). Panel B of Table 2 provides further descriptive statistics for the audit committee members highlighting several differences between male and female audit committee members. Panel $\mathrm{C}$ of Table 2 reports the p-value of a test for the difference in means between firms in the pre- and post-ASX CGC 2010 periods. Sample size is 10,013 firm-year observations.

Variable definitions are provided in Appendix A.

committee members (\#ACFemale), respectively. In all three models, the audit committee gender diversity variable is positive and significant (t-statistics $=5.854,6.111$, and 6.394, respectively; all p-values $<0.01$ ). This supports the complementary role that audit committees have within corporate governance, consistent with prior research. Similar to past studies, we also find that all our audit committee variables (except audit committee independence and tenure) are positively and significantly associated with audit fees. In addition, we find higher audit fees are associated with larger firms ( $L n+T A)$, a greater number of subsidiaries (Sub), business and geographical segments (Bus_Seg and Geo_Seg), higher inventory and receivables (Inv_Rec), and lower market-to-book ratio (MB). Finally, Big 4 firms (Big4), auditor tenure (Aud_Tenure), and nonaudit fees ( Ln NAS) are positively related to audit fees. However, we find no association between auditor industry specialization or auditor gender and audit fees. The adjusted $\mathrm{R}^{2}$ for all three models is around 75 percent. Overall, these results confirm that, for our sample, the unconditional association between greater female representation on the audit committee and audit fees, our first measure of audit quality, is positive and significant. ${ }^{14,15}$

Table 4 reports the baseline results using real earnings management, our second measure of audit quality. Consistent with the complementary view, the coefficients on the three measures for audit committee gender diversity are negative and significant in all models shown in Table 4, suggesting that firms with female members on the audit committee have lower real earnings management and, therefore, higher audit quality. ${ }^{16}$ In terms of the control variables, the coefficients for firm size, return on assets, and board independence are consistently significant and have signs consistent with prior literature. Together, the results in Tables 3 and 4 indicate that there is an unconditional relation between audit committee gender diversity and audit quality that is consistent with the audit committee having a complementary corporate governance role. ${ }^{17}$

To examine H1, we estimate Equations (6) and (7). Table 5 provides the results. We discuss the results for the proportion of women on the audit committee measure (\%ACFemale), but our results are consistent for all three audit committee gender measures. In Column 1 of Table 5, the coefficient for \%ACFemale is positive and highly significant (t-statistic $=12.367$; $\mathrm{p}$ value $<0.01)$. This indicates that firms with a greater proportion of female audit committee members had higher audit fees in the pre-ASX CGC 2010 period. The positive relation is consistent with our finding for the relation between \%ACFemale and audit fees for the entire sample period (Table 3).

14 We also estimate Equation (4) using the natural log of total fees-audit fees plus nonaudit fees-as the dependent variable. For this specification, we omit Ln_NAS as a control variable. The results (untabulated) are qualitatively similar to the results in Table 3 as all three audit committee gender diversity variables are positive and significant.

15 To corroborate our baseline findings, we use abnormal audit fees as an alternative measure to logged audit fees. Consistent with our expectations, the untabulated results suggest that firms with female audit committee members (across all three measures of gender diversity) pay higher abnormal audit fees, suggesting that female audit committee members demand greater audit coverage in order to ensure higher levels of audit quality (t-statistics $=$ $5.682,5.751$, and 6.054 , for the three measures of gender diversity).

16 We also use McNichols's (2002) accrual-based measure of discretionary accruals as an alternative measure of earnings quality. Untabulated regression results confirm our baseline findings that firms with female members on the audit committee exhibit higher audit quality.

17 In order to confirm that our results related to real earnings management are not driven by board diversity, we performed additional analyses. First, we include board gender diversity as an added control variable in our main model specified in Equation (5). Audit committee gender diversity continues to be significant ( $\mathrm{t}$-statistic $=-4.389)$, while board gender diversity is not significant ( $\mathrm{t}$-statistic $=1.075)$, indicating that audit committee gender diversity is driving our results. To further corroborate our findings, we perform a mediation analysis following Baron and Kenny (1986). Untabulated results indicate that board gender diversity is not significantly related to Comp_REM when Comp_REM is regressed on (1) board gender diversity and control variables, and (2) board gender diversity, audit committee gender diversity, and control variables, confirming that audit committee gender diversity is driving the results in Table 4. 
FIGURE 1

Female Representation on Audit Committees by Year

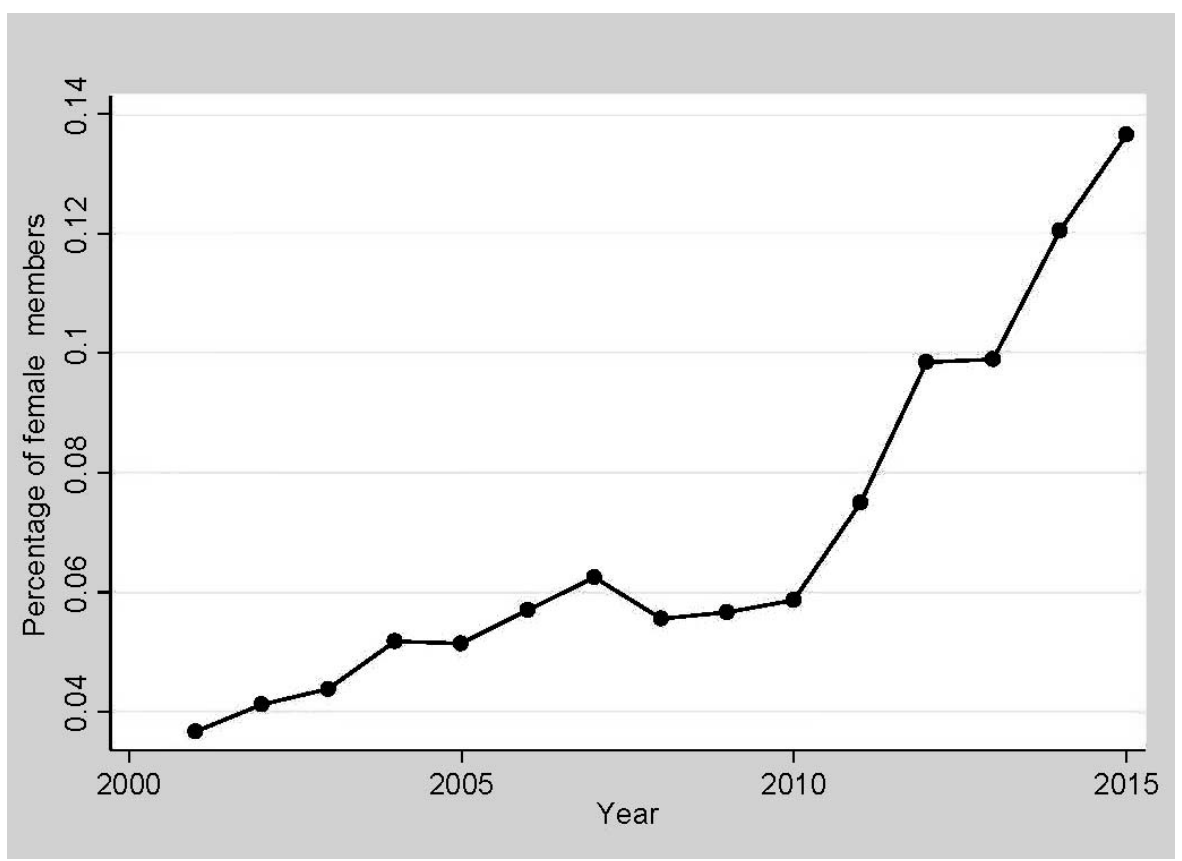

The variable of interest, \%ACFemale $*$ POST, has a negative and significant coefficient (t-statistic $=-4.816$; $\mathrm{p}$-value $<$ 0.01 ), which indicates that the relation between the proportion of women audit committee members and audit fees was less positive, or weaker, in the period after the ASX CGC gender diversity recommendations were released in 2010. This finding is consistent with the limited supply view in that audit committees with women members after 2010 do not appear to demand as much audit quality as audit committees with women members in the pre-ASX CGC 2010 period. However, notably, the combined coefficient for \%ACFemale and \%ACFemale * POST is equal to $0.512(1.117-0.605)$, which is also significant (Fstatistic $=18.073 ;$ p-value $<0.01)$. Thus, there is still a positive association between the proportion of women on the audit committee and audit fees post-ASX CGC 2010. Thus, while the gender diversity effect on audit quality was diminished in the post-ASX CGC 2010 period, it did not completely disappear, at least when audit fees are used as the measure of audit quality.

Columns 4 to 6 of Table 5, Panel B provide the results for $\mathrm{H} 1 \mathrm{using}$ real earnings management as the measure of audit quality. The coefficient for \%ACFemale is negative and significant ( $\mathrm{t}$-statistic $=-2.956$; $\mathrm{p}$-value $<0.01$ ), which is consistent with the full sample results in Table 4. This indicates that, in the period before the ASX CGC guidelines were introduced in 2010, greater female representation on the audit committee is associated with less real earnings management or higher audit quality. The variable of interest, $\%$ ACFemale $*$ POST, has a positive and significant coefficient $(\mathrm{t}$-statistic $=2.168$; $\mathrm{p}$-value $<0.05$ ), indicating that, compared to the pre-ASX CGC 2010 period, there was an incremental increase in the relation between the proportion of female audit committee members and Comp REM, indicating that the performance of more gender-diverse audit committees diminished in the post-ASX CGC 2010 period. This finding is also consistent with the limited supply view where firms hire less qualified women directors after the ASX CGC 2010 guidelines. Similar to Column 1, in Column 4, the combined coefficient for \%ACFemale and \%ACFemale $*$ POST is significantly different from $0(\mathrm{~F}$-statistic $=11.753$; $\mathrm{p}$-value $<0.01)$. Thus, the relation between audit committee gender diversity and real earnings management in the post-ASX CGC 2010 period remains negative and significant. Nonetheless, the results in both Tables 5 and 6 are consistent with the ASX CGC 2010 gender diversity guidelines diluting the performance of gender-diverse boards. ${ }^{18,19}$

\footnotetext{
${ }^{18}$ To control for the effect of the global financial crisis (GFC) on the association between audit committee gender diversity and audit quality, we perform tests for the baseline model where regressions are re-run using GFC as an indicator variable that equals 1 for the GFC period (2007-2009), and 0 otherwise. Untabulated results indicate that, although the two-way interaction between audit committee gender diversity and GFC is not significant, the coefficients on audit committee gender diversity remain positive and highly significant for all regressions for both audit fees and real earnings management. In addition, we also run tests for H1 where regressions (specified in Equations (6) and (7)) are re-run excluding GFC years (i.e., 20072009) and the results are highly similar to those reported in Table 5. These results suggest that the GFC period does not impact our findings.

19 Our results are qualitatively unchanged when auditor fixed effects are included.
} 
TABLE 3 Audit Fees and Audit Committee Gender Diversity

\begin{tabular}{|c|c|c|c|}
\hline Variable & $\begin{array}{c}\% \text { ACFemale } \\
\text { (1) }\end{array}$ & $\begin{array}{c}\text { DumACFemale } \\
\text { (2) }\end{array}$ & $\begin{array}{c}\text { \#ACFemale } \\
\text { (3) }\end{array}$ \\
\hline ACGenderDiversity & $\begin{array}{l}0.859^{* * *} \\
(5.854)\end{array}$ & $\begin{array}{l}0.308^{* * *} \\
(6.111)\end{array}$ & $\begin{array}{l}0.269 * * * \\
(6.394)\end{array}$ \\
\hline$\% A C I n d$ & $\begin{array}{l}-0.020 \\
(-0.332)\end{array}$ & $\begin{array}{l}-0.005 \\
(-0.078)\end{array}$ & $\begin{array}{l}0.006 \\
(0.097)\end{array}$ \\
\hline ACSize & $\begin{array}{l}0.073^{* * *} \\
(6.964)\end{array}$ & $\begin{array}{l}0.066^{* * * *} \\
(6.277)\end{array}$ & $\begin{array}{l}0.062 * * * \\
(5.933)\end{array}$ \\
\hline ACMeet & $\begin{array}{l}0.058^{* * * *} \\
(5.566)\end{array}$ & $\begin{array}{l}0.059^{* * * *} \\
(5.602)\end{array}$ & $\begin{array}{l}0.061 * * * \\
(5.846)\end{array}$ \\
\hline$\%$ ACFin & $\begin{array}{l}0.212 * * * \\
(3.126)\end{array}$ & $\begin{array}{l}0.206^{* * *} \\
(3.029)\end{array}$ & $\begin{array}{l}0.207 * * * \\
(3.051)\end{array}$ \\
\hline ACTenure & $\begin{array}{c}0.001 \\
(1.440)\end{array}$ & $\begin{array}{c}0.001 \\
(1.441)\end{array}$ & $\begin{array}{c}0.001 \\
(1.431)\end{array}$ \\
\hline ACMul & $\begin{array}{l}0.041^{* * * *} \\
(2.930)\end{array}$ & $\begin{array}{l}0.041^{* * *} \\
(2.970)\end{array}$ & $\begin{array}{l}0.042 * * * \\
(2.995)\end{array}$ \\
\hline Duality & $\begin{array}{c}0.039 \\
(1.070)\end{array}$ & $\begin{array}{c}0.040 \\
(1.081)\end{array}$ & $\begin{array}{c}0.037 \\
(1.022)\end{array}$ \\
\hline BSize & $\begin{array}{l}0.104 * * * \\
(4.466)\end{array}$ & $\begin{array}{l}0.103 * * * \\
(4.383)\end{array}$ & $\begin{array}{l}0.102 * * * \\
(4.379)\end{array}$ \\
\hline BoDInd & $\begin{array}{l}0.196^{* *} \\
(2.332)\end{array}$ & $\begin{array}{l}0.183 * * \\
(2.191)\end{array}$ & $\begin{array}{l}0.167 * * \\
(2.014)\end{array}$ \\
\hline$L n \_N A S$ & $\begin{array}{c}0.041^{* * * *} \\
(12.280)\end{array}$ & $\begin{array}{l}0.041^{* * *} \\
(12.278)\end{array}$ & $\begin{array}{l}0.041^{* * * *} \\
(12.257)\end{array}$ \\
\hline Big4 & $\begin{array}{l}0.399 * * * \\
(9.945)\end{array}$ & $\begin{array}{l}0.397 * * * \\
(9.951)\end{array}$ & $\begin{array}{c}0.400^{* * * *} \\
(10.002)\end{array}$ \\
\hline Aud_Gender & $\begin{array}{c}0.004 \\
(0.869)\end{array}$ & $\begin{array}{c}0.004 \\
(0.935)\end{array}$ & $\begin{array}{c}0.003 \\
(0.734)\end{array}$ \\
\hline Aud_Ind-Specialist & $\begin{array}{l}-0.044 \\
(-0.895)\end{array}$ & $\begin{array}{l}-0.045 \\
(-0.920)\end{array}$ & $\begin{array}{c}-0.043 \\
(-0.869)\end{array}$ \\
\hline Aud_Tenure & $\begin{array}{l}0.110^{* *} \\
(2.047)\end{array}$ & $\begin{array}{l}0.109 * * \\
(2.033)\end{array}$ & $\begin{array}{l}0.106^{* *} \\
(1.986)\end{array}$ \\
\hline Ln_TA & $\begin{array}{l}0.131 * * * \\
(7.887)\end{array}$ & $\begin{array}{l}0.130 * * * \\
(7.834)\end{array}$ & $\begin{array}{l}0.130^{* * * *} \\
(7.888)\end{array}$ \\
\hline$R O A$ & $\begin{array}{l}-0.072 * * * \\
(-2.678)\end{array}$ & $\begin{array}{l}-0.070^{* *} \\
(-2.604)\end{array}$ & $\begin{array}{l}-0.069 * * * \\
(-2.597)\end{array}$ \\
\hline$M B$ & $\begin{array}{l}-0.014 * * * \\
(-3.561)\end{array}$ & $\begin{array}{l}-0.014 * * * \\
(-3.633)\end{array}$ & $\begin{array}{l}-0.014 * * * \\
(-3.662)\end{array}$ \\
\hline Leverage & $\begin{array}{l}0.054 * * * \\
(4.773)\end{array}$ & $\begin{array}{l}0.054 * * * \\
(4.842)\end{array}$ & $\begin{array}{l}0.055^{* * *} \\
(4.864)\end{array}$ \\
\hline Inv_Rec & $\begin{array}{l}1.426^{* * *} \\
(6.573)\end{array}$ & $\begin{array}{l}1.428 * * * \\
(6.593)\end{array}$ & $\begin{array}{l}1.435^{* * *} \\
(6.648)\end{array}$ \\
\hline Sub & $\begin{array}{l}0.009 * * * \\
(9.981)\end{array}$ & $\begin{array}{l}0.009 * * * \\
(9.946)\end{array}$ & $\begin{array}{l}0.009 * * * \\
(9.789)\end{array}$ \\
\hline Bus_Seg & $\begin{array}{l}0.042^{* * *} \\
(2.923)\end{array}$ & $\begin{array}{l}0.041^{* * *} \\
(2.862)\end{array}$ & $\begin{array}{l}0.042 * * * \\
(2.967)\end{array}$ \\
\hline Geo_Seg & $\begin{array}{l}0.038^{* *} \\
(2.300)\end{array}$ & $\begin{array}{l}0.037 * * \\
(2.257)\end{array}$ & $\begin{array}{l}0.039 * * \\
(2.403)\end{array}$ \\
\hline Constant & $\begin{array}{c}6.749 * * * \\
(22.249)\end{array}$ & $\begin{array}{c}0.014 * * * \\
(22.482)\end{array}$ & $\begin{array}{l}6.806^{* * *} \\
(22.814)\end{array}$ \\
\hline $\begin{array}{l}\mathrm{n} \\
\text { Adjusted } \mathrm{R}^{2}\end{array}$ & $\begin{array}{r}10,013 \\
0.752\end{array}$ & $\begin{array}{c}10,013 \\
0.751\end{array}$ & $\begin{array}{r}10,013 \\
0.753\end{array}$ \\
\hline
\end{tabular}

$*, * *, * * *$ Represent two-tailed statistical significance at the 10 percent, 5 percent, and 1 percent levels, respectively.

Table 3 presents regression results for a baseline model where audit quality is captured by audit fees. The dependent variable is $L n \_A u d F e e$. t-statistics (reported in parentheses) are based on robust standard errors clustered at firm level. Firm and year fixed effects are included.

Variable definitions are provided in Appendix A. 
TABLE 4

Real Earnings Management and Audit Committee Gender Diversity

\begin{tabular}{|c|c|c|c|}
\hline Variable & $\begin{array}{c}\text { \%ACFemale } \\
\text { (1) }\end{array}$ & $\begin{array}{c}\text { DumACFemale } \\
\text { (2) }\end{array}$ & $\begin{array}{c}\text { \#ACFemale } \\
\text { (3) }\end{array}$ \\
\hline ACGenderDiversity & $\begin{array}{l}-0.450^{* * *} \\
(-4.423)\end{array}$ & $\begin{array}{l}-0.150 * * * \\
(-4.105)\end{array}$ & $\begin{array}{l}-0.126^{* * *} \\
(-4.516)\end{array}$ \\
\hline$L n \_T A$ & $\begin{array}{l}0.057 * * * \\
(3.377)\end{array}$ & $\begin{array}{l}0.058 * * * \\
(3.429)\end{array}$ & $\begin{array}{l}0.058 * * * \\
(3.423)\end{array}$ \\
\hline$M B$ & $\begin{array}{l}-0.004 \\
(-0.476)\end{array}$ & $\begin{array}{l}-0.003 \\
(-0.422)\end{array}$ & $\begin{array}{c}-0.003 \\
(-0.462)\end{array}$ \\
\hline Leverage & $\begin{array}{c}0.018 \\
(1.076)\end{array}$ & $\begin{array}{l}0.018 \\
(1.067)\end{array}$ & $\begin{array}{c}0.018 \\
(1.072)\end{array}$ \\
\hline$R O A$ & $\begin{array}{l}-0.231^{* * *} \\
(-3.592)\end{array}$ & $\begin{array}{l}-0.232 * * * \\
(-3.614)\end{array}$ & $\begin{array}{l}-0.233^{* * *} \\
(-3.624)\end{array}$ \\
\hline $\mathrm{CFO}_{-} \mathrm{Vol}$ & $\begin{array}{c}0.000 \\
(1.136)\end{array}$ & $\begin{array}{c}0.000 \\
(1.133)\end{array}$ & $\begin{array}{c}0.000 \\
(1.239)\end{array}$ \\
\hline Rev_Vol & $\begin{array}{l}-0.000 \\
(-1.079)\end{array}$ & $\begin{array}{l}-0.000 \\
(-0.983)\end{array}$ & $\begin{array}{l}-0.000 \\
(-1.079)\end{array}$ \\
\hline Loss & $\begin{array}{c}0.020 \\
(0.448)\end{array}$ & $\begin{array}{c}0.019 \\
(0.430)\end{array}$ & $\begin{array}{c}0.020 \\
(0.452)\end{array}$ \\
\hline Big4 & $\begin{array}{l}-0.053 \\
(-1.518)\end{array}$ & $\begin{array}{l}-0.054 \\
(-1.536)\end{array}$ & $\begin{array}{l}-0.054 \\
(-1.551)\end{array}$ \\
\hline Duality & $\begin{array}{l}-0.029 \\
(-0.257)\end{array}$ & $\begin{array}{c}-0.029 \\
(-0.253)\end{array}$ & $\begin{array}{l}-0.030 \\
(-0.263)\end{array}$ \\
\hline ACSize & $\begin{array}{l}-0.021 \\
(-1.437)\end{array}$ & $\begin{array}{l}-0.018 \\
(-1.198)\end{array}$ & $\begin{array}{l}-0.016 \\
(-1.100)\end{array}$ \\
\hline$\% A C I n d$ & $\begin{array}{l}-0.057 * * * \\
(-3.377)\end{array}$ & $\begin{array}{c}0.016 \\
(0.201)\end{array}$ & $\begin{array}{c}0.013 \\
(0.155)\end{array}$ \\
\hline ACMeet & $\begin{array}{l}-0.021 * * \\
(-2.312)\end{array}$ & $\begin{array}{l}-0.022 * * \\
(-2.330)\end{array}$ & $\begin{array}{l}-0.022^{* *} \\
(-2.415)\end{array}$ \\
\hline$\%$ ACFin & $\begin{array}{c}0.040 \\
(0.546)\end{array}$ & $\begin{array}{c}0.039 \\
(0.536)\end{array}$ & $\begin{array}{c}0.043 \\
(0.581)\end{array}$ \\
\hline ACTenure & $\begin{array}{l}0.002 * * \\
(2.185)\end{array}$ & $\begin{array}{l}0.002 * * \\
(2.187)\end{array}$ & $\begin{array}{l}0.002 * * \\
(2.199)\end{array}$ \\
\hline$A C M u l$ & $\begin{array}{l}-0.026^{* *} \\
(-2.006)\end{array}$ & $\begin{array}{l}-0.027 * * \\
(-2.059)\end{array}$ & $\begin{array}{l}-0.027 * * \\
(-2.056)\end{array}$ \\
\hline BSize & $\begin{array}{c}0.002 \\
(0.165)\end{array}$ & $\begin{array}{c}0.002 \\
(0.179)\end{array}$ & $\begin{array}{c}0.002 \\
(0.204)\end{array}$ \\
\hline BoDInd & $\begin{array}{l}-0.731 \text { *** } \\
(-2.617)\end{array}$ & $\begin{array}{l}-0.755^{* * *} \\
(-2.690)\end{array}$ & $\begin{array}{l}-0.753^{* * *} \\
(-2.682)\end{array}$ \\
\hline Constant & $\begin{array}{l}-0.093 \\
(-1.743)\end{array}$ & $\begin{array}{c}-0.083 \\
(-0.668)\end{array}$ & $\begin{array}{c}-0.080 \\
(-0.638)\end{array}$ \\
\hline $\mathrm{n}$ & 10,013 & 10,013 & 10,013 \\
\hline Adjusted $\mathrm{R}^{2}$ & 0.479 & 0.470 & 0.481 \\
\hline
\end{tabular}

$*, * *, * * *$ Represent two-tailed statistical significance at the 10 percent, 5 percent, and 1 percent levels, respectively.

Table 4 presents regression results for a baseline model where audit quality is captured by real earnings management. The dependent variable is Comp REM. t-statistics (reported in parentheses) are based on robust standard errors clustered at firm level. Firm and year fixed effects are included.

Variable definitions are provided in Appendix A.

To shed further light on this issue, we extend our main analysis by considering when each female director was initially appointed to the audit committee. We subdivide the sample into two groups: (1) firms where females are appointed to an allmale board only after the introduction of the ASX CGC guidelines in 2010, and (2) firms where female audit committee members are initially appointed in the period before the ASX CGC guidelines were issued in 2010.

Table 6 reports the results. Columns 1 to 3 of Panel A show that \%ACFemale, DumACFemale, and \#ACFemale are positively and significantly associated for the pre-ASX CGC 2010 appointments (t-statistics = 3.912, 3.654, 3.994, 
TABLE 5

Panel A: Audit Fees

Variable
\%ACFemale
DumACFemale
\#ACFemale
POST
\%ACFemale * POST
DumACFemale * POST
\#ACFemale * POST
Control Variables
Constant
$\mathrm{n}$
Adjusted $\mathrm{R}^{2}$

Panel B: Real Earnings Management

Variable
\%ACFemale
DumACFemale
\#ACFemale
POST
\%ACFemale * POST
DumACFemale * POST
\#ACFemale * POST
Control Variables
Constant
$\mathrm{n}$
Adjusted $\mathrm{R}^{2}$

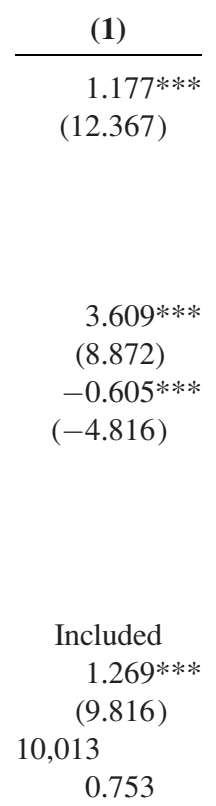

$-0.459 * * *$ $(-2.956)$

0.048

(1.336)

0.033 **

(2.168)$$
\text { (2.168) }
$$

(2)

$0.427 * * *$

(13.426)

$3.588 * * *$

(8.678)

$-0.238 * * *$

$$
(-5.651)
$$

Included

$1.312 * * *$

(9.337)

10,013

0.753

(5)

$0.377 * * *$

(14.625)

$3.599 * * *$

(8.921)

(3)

$-0.198 * * *$

$(-6.070)$

Included

$1.311 * * *$

(9.576)

10,013

0.754

$\begin{array}{ccc} & 0.044 * * * & \\ & & \\ & & \\ & & \\ & & \\ & & \\ \text { Included } & \text { Included } & \text { (.685) } \\ -0.752^{* * * *} & -0.779^{* * *} & \text { Included } \\ (-3.022) & (-3.107) & -0.775^{* * *} \\ 10,013 & 10,013 & (-3.092) \\ 0.367 & 0.369 & 10,013 \\ & & 0.360\end{array}$

$*, * *, * * *$ Represent two-tailed statistical significance at the 10 percent, 5 percent, and 1 percent levels, respectively.

Table 5 presents regression results for $\mathrm{H} 1$ where audit quality is captured by audit fees (Panel A) and real earnings management (Panel B). The dependent variable is Ln AudFee in Panel A and Comp REM in Panel B. Control variables are as shown in Table 3 for Panel A and Table 4 for Panel B. t-statistics (reported in parentheses) are based on robust standard errors clustered at firm level. Firm fixed effects are included. Variable definitions are provided in Appendix A. 
TABLE 6

Panel A: Audit Fees

\begin{tabular}{|c|c|c|c|c|c|c|}
\hline \multirow[b]{2}{*}{ Variable } & \multicolumn{3}{|c|}{$\begin{array}{l}\text { Initial Appointment in Pre-ASX } \\
\text { CGC } 2010 \text { Period and Continues } \\
\text { in Post-ASX CGC } 2010 \text { Period }\end{array}$} & \multicolumn{3}{|c|}{$\begin{array}{l}\text { Initial Appointment } \\
\text { Post-ASX CGC } 2010\end{array}$} \\
\hline & (1) & (2) & (3) & (4) & (5) & (6) \\
\hline$\%$ ACFemale & $\begin{array}{l}0.860 * * * \\
(3.912)\end{array}$ & & & $\begin{array}{l}-0.186 \\
(-0.503)\end{array}$ & & \\
\hline DumACFemale & & $\begin{array}{l}0.305^{* * *} \\
(3.654)\end{array}$ & & & $\begin{array}{l}-0.073 \\
(-0.373)\end{array}$ & \\
\hline \#ACFemale & & & $\begin{array}{l}0.242 * * * \\
(3.994)\end{array}$ & & & $\begin{array}{l}-0.073 \\
(-0.936)\end{array}$ \\
\hline Control Variables & Included & Included & Included & Included & Included & Included \\
\hline Constant & $\begin{array}{l}0.034 * * \\
(2.132)\end{array}$ & $\begin{array}{l}0.077 * * \\
(2.176)\end{array}$ & $\begin{array}{l}0.088^{* *} \\
(2.479)\end{array}$ & $\begin{array}{l}0.576^{* * *} \\
(9.111)\end{array}$ & $\begin{array}{l}0.641^{* * *} \\
(9.320)\end{array}$ & $\begin{array}{l}0.221^{* * *} \\
(9.261)\end{array}$ \\
\hline $\mathrm{n}$ & 3,026 & 3,026 & 3,026 & 986 & 986 & 986 \\
\hline Adjusted $\mathrm{R}^{2}$ & 0.606 & 0.610 & 0.608 & 0.458 & 0.458 & 0.459 \\
\hline
\end{tabular}

Panel B: Real Earnings Management

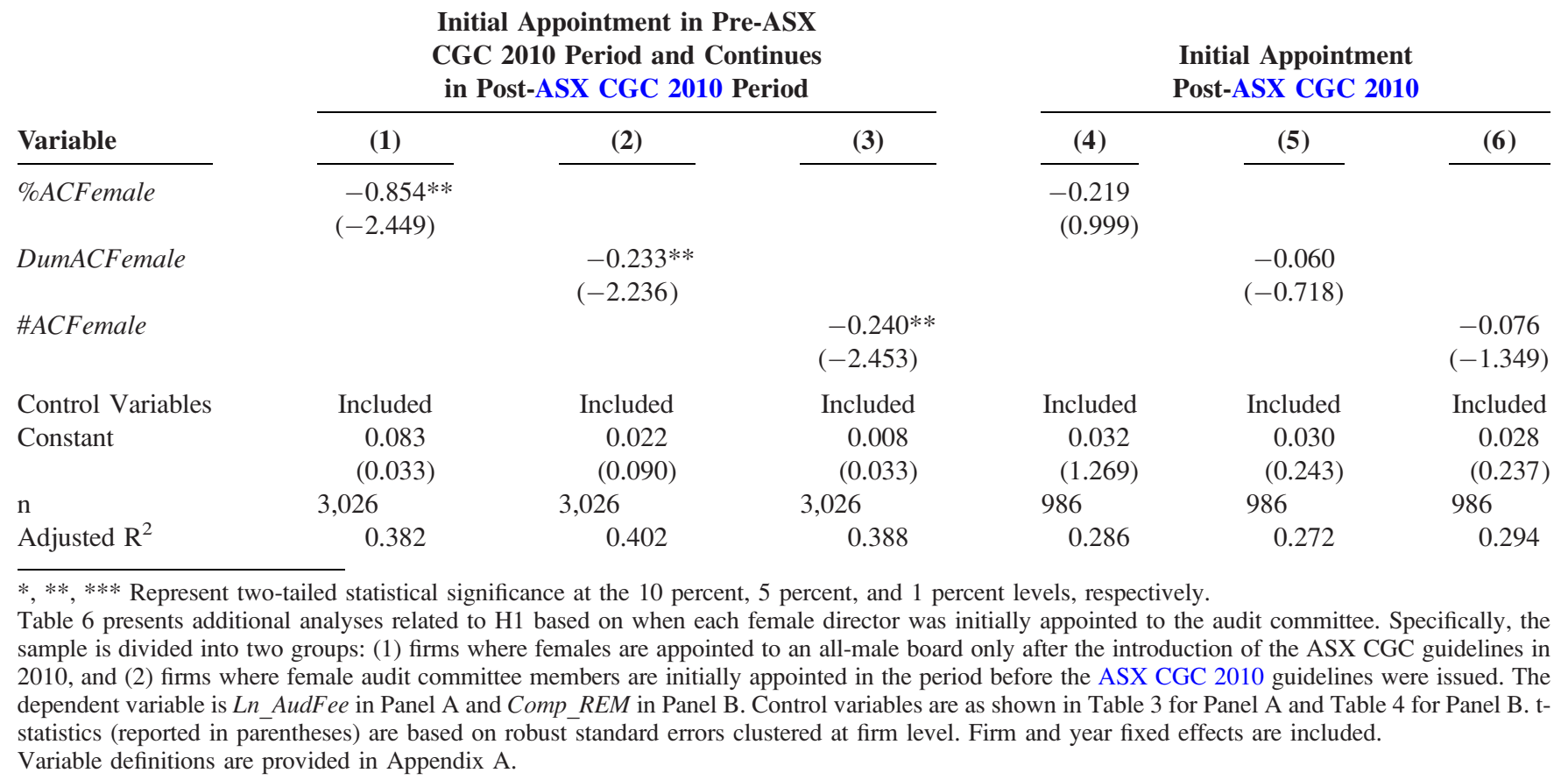

respectively; all p-values $<0.01$ ). In contrast, Columns 4 to 6 of Panel A indicate that none of our three measures of audit committee gender diversity are associated with audit fees for the sample of post-ASX CGC 2010 guideline appointments. Similar to results reported above in Panel A, Columns 1 to 3 of Panel B show that \%ACFemale, DumACFemale, and \#ACFemale are negatively and significantly associated with REM for the pre-ASX CGC 2010 appointments (t-statistics = $-2.449,-2.236,-2.453$, respectively; all p-values $<0.05)$. In contrast, Columns 4 to 6 of Panel A indicate that none of our three measures of audit committee gender diversity are associated with REM for the sample of post-ASX CGC 2010 guideline appointments. 
Thus, the results in Table 6 indicate that female audit committee member appointments after the introduction of ASX CGC 2010 guidelines are not as effective compared to appointments made before the guidelines. This provides further support for the limited supply view. ${ }^{20}$

Past literature suggests that shifting the tokenism of women directors toward a critical mass improves board performance significantly. ${ }^{21}$ We perform further analyses to see whether increasing the number of female directors on the audit committee has any differing impact on audit quality pre- and post-ASX CGC 2010 gender diversity guidelines. To measure this empirically, we create two indicators where (1) Add_Fem is given a score of 1 if an additional female is appointed where there is at least one female member already on the audit committee, and (2) Fem_Replace_Male is given a score of 1 if a female audit committee member replaces a male audit committee member. To test H1, we interact these variables with POST.

The results reported in Columns 1-2 and 4-5 of Table 7 show that both the coefficients for Add_Fem and Fem_Replace_ Male are positive (negative) when Ln_AudFee (Comp_REM) is the dependent variable, consistent with greater gender diversity improving audit committee performance in the pre-ASX CGC 2010 period. More importantly, the interactions, Add_Fem * POST and Fem_Replace_Male * POST, which reflect the incremental effect of these variables in the post-ASX CGC period, are negative (positive) when Ln_AudFee (Comp_REM) is the dependent variable. This indicates that adding a female member or replacing a male audit committee member with a female audit committee member improves audit committee performance more in the pre-ASX CGC 2010 period than in the post-ASX CGC 2010 period, providing further support for $\mathrm{H} 1$.

We also perform additional analyses to test the impact of changes in female participation on the audit committee (i.e., ChangeFem) on the year-to-year changes in audit fees (i.e., Chg_LnAudFee) and change in the level of real earnings management (i.e., ChangeREM). Results reported in Columns 3 and 6 of Table 7 suggest that changes in female members on the audit committee have a significant impact on changes in audit fees and the level of real earnings management, and that the impact is greater before the ASX CGC 2010 guidelines than after the guidelines were issued. Overall, the results in Table 7 suggest that female audit committee member appointments after the introduction of ASX CGC 2010 guidelines are not as effective compared to appointments made before the guidelines, further reinforcing the limited supply view.

\section{Endogeneity}

Endogeneity may occur if firms with higher audit fees choose female directors for their audit committees. In other words, firms with more diverse audit committees may be fundamentally different from firms that do not have gender-diverse audit committees, leading to a self-selection bias. Although we already control for firm fixed effects in our main analysis, we employ propensity score matching to control for the differences in firm characteristics between firms with at least a female director on the audit committee and firms without such arrangements (Dehejia and Wahba 2002; LaLonde 1986; Rosenbaum and Rubin 1983; Rubin and Thomas 1996). First, in order to construct a matched sample of treated-control pairs, we generate a propensity score using a logit regression to predict the likelihood of a female audit committee member on a firm based on all the control variables in Equations (4) and (5), respectively. We then match each firm with a female audit committee member using the nearest neighbor matching method, without replacement, with a firm without a female audit committee member that has the closest propensity score from the logit regression. Next, we pool the treatment sample and matched sample together and examine the differences between firms with female audit committee members and firms without such female audit committee

\footnotetext{
${ }^{20}$ We also consider whether the observed effect of gender diversity runs through the auditor (i.e., audit committees with more women are more likely to select a female auditor, which, in turn, affects audit quality and audit fees). In order to explore this, we perform a mediation analysis following Baron and Kenny (1986), who adopt a four-step approach in which several regression analyses are conducted, and the significance of the coefficients are examined in each step. In untabulated results, we find no association between audit committee gender and auditor gender, suggesting that mediation is not possible or likely. However, when continuing further to see if there is any association between auditor gender and audit fees, the results suggest that auditor gender is not significantly related to audit fees. Finally, when both auditor and audit committee gender diversity are regressed against audit fees, audit committee diversity continues to be significant while auditor gender continues to be insignificant, further determining that it is audit committee gender diversity that influences our results. We corroborate these findings above by using two other approaches of mediation analysis undertaken by Judd and Kenny (1981) and Sobel (1982). Results from all of these approaches of mediation provide consistent results indicating that the observed effect of gender diversity is not running through the auditor.

21 Kogut, Colomer, and Belinky (2014) document that, while achieving a set target or a mandated gender quota system is costly for firms to implement, having such quotas/targets help break the endogenous male-dominated board structure by shifting the tokenism of women directors toward a critical mass so that these women can have a real say in decision-making rather than being a lone voice that can be disregarded. Similar to Kogut et al. (2014), Torchia, Calabro, and Huse (2011) use a Norwegian sample from 2005 to 2006 when a mandatory gender quota system was being implemented in Norway and examine whether moving from tokenism (when there is only one woman on a board) to critical mass (when there are at least three women on a board) helps improve firm innovation. Findings from their study suggest that as the number of women on a board increases toward a critical mass, the level of firm innovation improves.
} 
TABLE 7

Additional Analyses for H1 Based on Alternative Measures of Audit Committee Gender Diversity

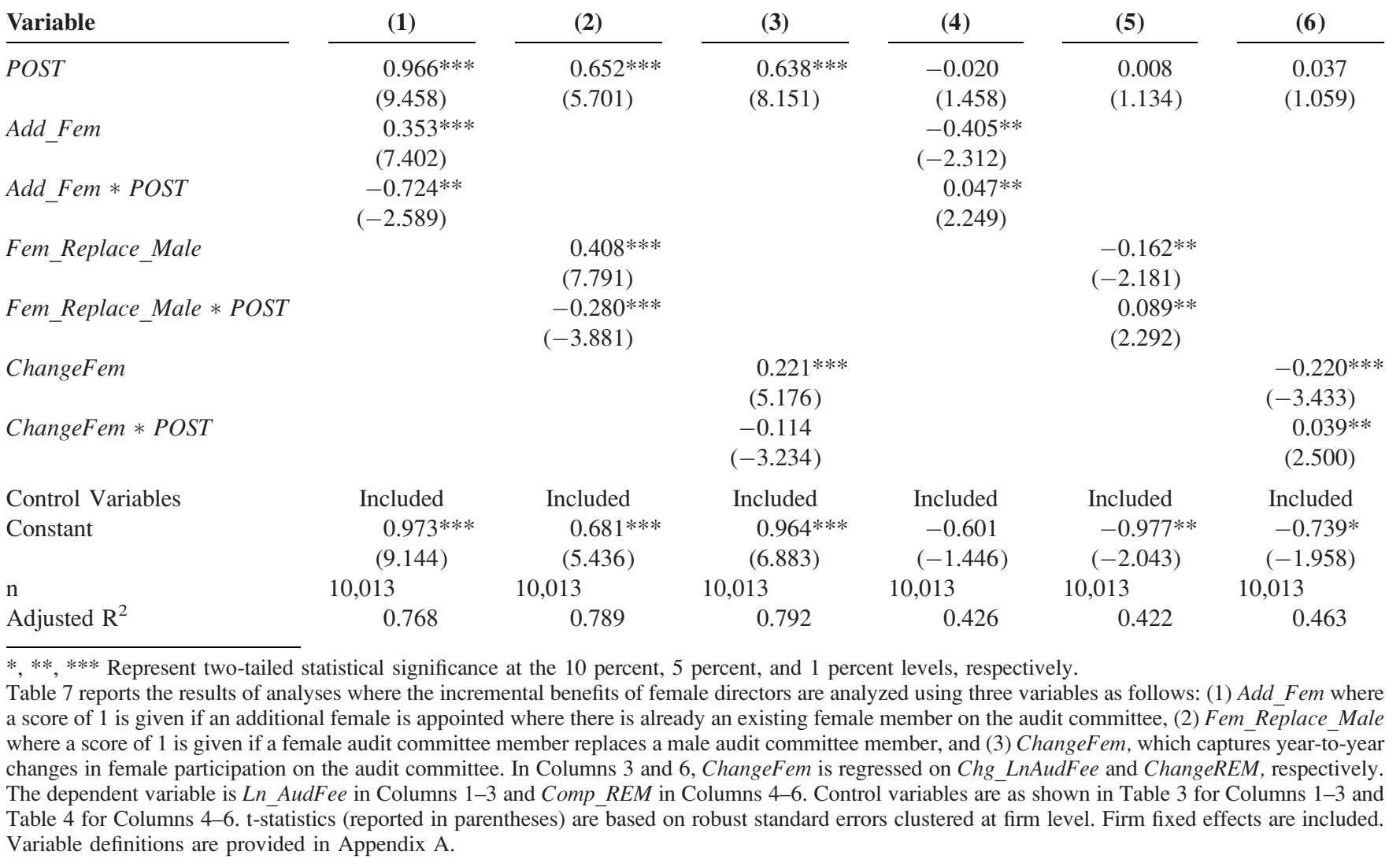

members in terms of audit quality. ${ }^{22}$ The propensity score matching produces a matched sample of 2,452 control firm-year observations resulting in a combined sample of 4,904 firm-year observations. We then re-run both Equations (4) and (5) using the matched sample. ${ }^{23}$

Table 8 presents the results of this test. Panel A (Panel B) reports the second stage regression results using the propensity score matching for audit fees (real earnings management). We find that the coefficient on DumACFemale is significant and remains positive for audit fees in Panel A (negative for real earnings management in Panel B), while the coefficient on DumACFemale * POST is significant and negative for audit fees (positive for real earnings management), confirming our main findings in Table 5.

In order to test the robustness of our matching method, we also incorporate two additional matching approaches. First, we perform the matching with replacement. Second, we also employ nearest neighbor matching within caliper with a tolerance level of 3 percent on the maximum propensity score distance (Rosenbaum and Rubin 1983, 1985). The results of both alternative matching approaches are consistent with the reported test results in Table 8.

Overall, these results indicate that endogeneity arising from self-selection bias is not likely to be driving our main results.

22 In order to test the quality/effectiveness of our matching, following Rosenbaum and Rubin (1985), we perform a two-sample t-test to check if there are any significant differences in the covariate means for both treatment and control groups. Before matching, there were significant differences between firms with female audit committee members and firms without such female members in terms of firm and governance characteristics and audit fees. However, after matching, there were no such significant differences. Consequently, the untabulated results from our t-tests suggest that our matching was effective.

23 An important step in propensity score matching is to assess the balance of the measured covariates between the treatment and comparison groups. To test the balance, we perform a balance test, results of which indicate that the Chi-square in the overall balance test is not significant $\left(\chi^{2}=2.993\right.$; $\mathrm{p}$-value $=0.761$ ). In addition, the multivariate imbalance measure indicates that the L1 (i.e., 0.634) is bigger for the unmatched sample than the L1 of the matched sample (0.291), suggesting that balance has improved after matching. 
TABLE 8

Panel A: Audit Fees

\begin{tabular}{l} 
Variable \\
\hline DumACFemale \\
POST \\
DumACFemale * POST \\
\%ACInd \\
ACSize \\
ACMeet \\
\%ACFin \\
ACTenure \\
ACMul \\
Duality \\
BSize \\
BoDInd \\
Ln_NAS \\
Big4 \\
Aud_Gender \\
Aud_Ind-Specialist \\
Aud_Tenure \\
Ln_TA \\
ROA \\
MB \\
Leverage \\
Inv_Rec \\
Sub \\
Bus_Seg \\
Geo_Seg \\
Constant \\
$\mathrm{n}$ \\
Adjusted R ${ }^{2}$ \\
\end{tabular}

$\begin{array}{rc}0.106 & (9.643)^{* * *} \\ 1.248 & (1.769)^{*} \\ -0.351 & (-6.849)^{* * *} \\ -0.100 & (-1.413) \\ 0.035 & (3.148)^{* * *} \\ 0.027 & (2.845)^{* * *} \\ 0.102 & (1.456) \\ 0.062 & (1.137) \\ 0.054 & (4.328)^{* * *} \\ 0.036 & (1.089) \\ 0.258 & (3.674)^{* * *} \\ 0.053 & (5.476)^{* * *} \\ 0.023 & (6.143)^{* * *} \\ 0.276 & (8.243)^{* * *} \\ 0.004 & (-0.100) \\ 0.012 & (0.329) \\ 0.020 & (4.056)^{* * *} \\ 0.084 & (11.672)^{* * *} \\ -0.210 & (-5.483)^{* * *} \\ -0.002 & (-0.582) \\ 0.020 & (2.739)^{* * *} \\ 1.418 & (8.370)^{* * *} \\ 0.005 & (10.722)^{* * *} \\ 0.010 & (1.169) \\ 0.041 & (4.250)^{* * *} \\ 0.724 & (6.193)^{* * *} \\ & 4,904 \\ & 0.889 \\ & \end{array}$

Panel B: Real Earnings Management

\begin{tabular}{l} 
Variable \\
\hline DumACFemale \\
POST \\
DumACFemale * POST \\
\%ACInd \\
ACSize \\
ACMeet \\
\%ACFin \\
ACTenure \\
ACMul \\
Duality \\
BSize \\
BoDInd \\
Big4 \\
Ln_TA \\
ROA \\
MB \\
Leverage \\
CFO_Vol
\end{tabular}

$\begin{array}{rc}-0.840 & (-2.248)^{* *} \\ 0.017 & (0.172) \\ 0.149 & (1.993)^{* *} \\ -0.262 & (-1.19) \\ -0.084 & (-2.290)^{*} \\ -0.274 & (-1.706)^{*} \\ -0.548 & (-1.236) \\ 0.012 & (1.652) \\ -0.471 & (-2.167)^{* *} \\ -0.252 & (-1.393) \\ -0.251 & (-1.165) \\ -0.146 & (-1.569) \\ -0.266 & (-.865)^{*} \\ 0.080 & (2.193)^{* *} \\ -0.626 & (-2.042)^{* *} \\ 0.001 & (0.868) \\ 0.004 & (0.843) \\ 0.069 & (1.820)^{*}\end{array}$

(continued on next page) 
TABLE 8 (continued)

\begin{tabular}{lrrr} 
Variable & & & \\
\cline { 1 - 2 } Rev_Vol & -0.293 & & $(-1.296)$ \\
Loss & 0.101 & & $(1.367)$ \\
Constant & -1.008 & & $(-1.239)$ \\
$\mathrm{n}$ & & 4,904 & \\
Adjusted $\mathrm{R}^{2}$ & & 0.323 &
\end{tabular}

$*, * *, * * *$ Represent two-tailed statistical significance at the 10 percent, 5 percent, and 1 percent levels, respectively.

Table 8 presents regression results addressing self-selection bias using propensity score matching. The dependent variable is $L n \_A u d F e e$ in Panel A and Comp REM in Panel B. Control variables are as shown in Table 3 for Panel A and Table 4 for Panel B. t-statistics (reported in parentheses) are based on robust standard errors clustered at firm level. Firm fixed effects are included.

Variable definitions are provided in Appendix A.

Another type of endogeneity is reverse causality, which can occur, for example, if female directors are more likely to join the audit committee of firms that pay high audit fees. To address this concern, we use a lag-lead approach to establish a temporal sequence (Dhaliwal, Li, Tsang, and Yang 2011). Specifically, we undertake analyses using the lead audit fees and lead earnings quality (i.e., in $t+1$ ), and, as reported in Table 9, the results relating to our three measures of audit committee gender diversity are qualitatively the same as in our main analyses for both lead audit fees (Panel A) and lead real earnings management (Panel B).

\section{CONCLUSION}

Boardroom gender diversity continues to be a prominent policy issue, and numerous countries around the world have adopted policies to promote greater female representation on boards. Based on recently enacted policies, governance code recommendations - a form of soft regulation-are three and a half times more likely to be used than hard regulations such as mandatory targets and quotas (Adams 2016). However, as prior studies have focused on mandatory gender diversity regulations, whether soft regulations are effective remains an open issue (Klettner et al. 2016; OECD 2004). In addition, prior research has not examined how gender diversity policies affect the inner workings of the board. Given that board effectiveness is ultimately linked to the performance of its subcommittees (e.g., Klein 1998), it is important to understand the effects of greater female representation at the subcommittee level.

In this study, we shed light on the efficacy of gender diversity recommendations in governance codes. We focus on the audit committee because, unlike the overall board, the audit committee has a narrow and well-defined role over financial reporting quality. This allows us to identify a few key indicators of audit committee performance. Thus, we shed light on the effect of gender diversity guidelines on one specific corporate governance role of board, i.e., monitoring financial reporting quality.

We focus on Australia where the ASX introduced gender diversity recommendations for listed firms in 2010. Our main results are as follows. We find that the strength of the association between the presence of female audit committee members and audit quality decreased after the gender diversity guidelines were released in 2010. This finding is consistent with firms appointing less qualified females to the audit committee in the post-ASX CGC 2010 period as the supply of qualified women did not increase commensurately with the increase in demand. Notably, in further analyses, we show that females initially appointed to the audit committee before 2010 continue to be associated with better audit quality in the post-ASX CGC 2010 period, whereas females initially appointed to the audit committee after 2010 do not improve audit quality. Overall, our results suggest that while female representation on the audit committee increased after the ASX CGC 2010 guidelines were issued, the strength of the association between female representation on the audit committee and audit quality declined. Thus, our results support the limited supply view where the guidelines created an exogenous shock that increased the demand for qualified women directors but did not lead to a corresponding increase in supply.

Our interpretation requires three caveats. First, our conclusion is based on economic outcomes. That is, we investigate whether the ASX CGC 2010 guidelines have strengthened the business case for gender diversity on the audit committee. We acknowledge that there is also an ethical case for gender diversity. Using that as a measuring stick, the ASX CGC 2010 guidelines have already had some success as we document a significant increase in female presence on the audit committee post-ASX CGC 2010.

Second, our interpretation is based on the assumption that a decrease in discrimination would lead to better firm-director matches in our setting. However, we do not test this assumption directly. If this assumption does not hold, interpreting our results become more ambiguous because the strength of the association between the presence of female audit committee 
TABLE 9

Lead-Lag Analyses

Panel A: Lead $(t+1)$ Audit Fees

\begin{tabular}{|c|c|c|c|c|c|c|}
\hline \multirow[b]{2}{*}{ Variable } & \multicolumn{3}{|c|}{ Full Sample } & \multicolumn{3}{|c|}{ Impact of ASX CGC 2010 Guidelines } \\
\hline & (1) & (2) & (3) & (4) & (5) & (6) \\
\hline POST & & & & $\begin{array}{l}0.335^{* * * *} \\
(10.608)\end{array}$ & $\begin{array}{l}0.348 * * * \\
(10.963)\end{array}$ & $\begin{array}{c}0.341 \text { *** } \\
(10.884)\end{array}$ \\
\hline$\%$ ACFemale & $\begin{array}{l}0.834 * * * \\
(4.961)\end{array}$ & & & $\begin{array}{l}1.265 * * * \\
(5.899)\end{array}$ & & \\
\hline$\%$ ACFemale $*$ POST & & & & $\begin{array}{l}-0.975^{* * *} \\
(-4.296)\end{array}$ & & \\
\hline DumACFemale & & $\begin{array}{l}0.287 * * * \\
(5.129)\end{array}$ & & & $\begin{array}{l}0.448 \text { *** } \\
(6.458)\end{array}$ & \\
\hline DumACFemale $*$ POST & & & & & $\begin{array}{l}-0.377 * * * \\
(-5.131)\end{array}$ & \\
\hline \#ACFemale & & & $\begin{array}{l}0.265^{* * * *} \\
(5.524)\end{array}$ & & & $\begin{array}{l}0.400 * * * \\
(6.571)\end{array}$ \\
\hline \#ACFemale $*$ POST & & & & & & $\begin{array}{l}-0.298 * * * \\
(-5.096)\end{array}$ \\
\hline Control Variables & Included & Included & Included & Included & Included & Included \\
\hline Constant & $\begin{array}{l}1.832^{* * *} \\
(21.607)\end{array}$ & $\begin{array}{l}1.871^{* * * *} \\
(21.790)\end{array}$ & $\begin{array}{l}1.887 * * * \\
(22.095)\end{array}$ & $\begin{array}{l}1.625^{* * *} \\
(17.010)\end{array}$ & $\begin{array}{l}1.663^{* * * *} \\
(17.048)\end{array}$ & $\begin{array}{l}1.663 \text { *** } \\
(17.452)\end{array}$ \\
\hline $\mathrm{n}$ & 10,013 & 10,013 & 10,013 & 10,013 & 10,013 & 10,013 \\
\hline Adjusted $\mathrm{R}^{2}$ & 0.689 & 0.689 & 0.691 & 0.695 & 0.696 & 0.700 \\
\hline
\end{tabular}

Panel B: Lead $(t+1)$ Real Earnings Management

\begin{tabular}{|c|c|c|c|c|c|c|}
\hline \multirow[b]{2}{*}{ Variable } & \multicolumn{3}{|c|}{ Full Sample } & \multicolumn{3}{|c|}{ Impact of ASX CGC 2010 Guidelines } \\
\hline & (1) & (2) & (3) & (4) & (5) & (6) \\
\hline POST & & & & $\begin{array}{c}0.065 \\
(1.549)\end{array}$ & $\begin{array}{c}0.062 \\
(1.523)\end{array}$ & $\begin{array}{l}0.086 \\
(1.577)\end{array}$ \\
\hline$\%$ ACFemale & $\begin{array}{l}-0.599 * * * \\
(-3.310)\end{array}$ & & & $\begin{array}{l}-0.251^{* *} \\
(-2.339)\end{array}$ & & \\
\hline$\%$ ACFemale $*$ POST & & & & $\begin{array}{l}0.333^{* * *} \\
(2.209)\end{array}$ & & \\
\hline DumACFemale & & $\begin{array}{l}-0.144 * * \\
(-2.288)\end{array}$ & & & $\begin{array}{l}-0.877^{*} \\
(-2.347)\end{array}$ & \\
\hline DumACFemale $*$ POST & & & & & $\begin{array}{l}0.140 * * \\
(2.259)\end{array}$ & \\
\hline \#ACFemale & & & $\begin{array}{l}-0.141 * * * \\
(-2.706)\end{array}$ & & & $\begin{array}{l}-0.711^{* *} \\
(-2.300)\end{array}$ \\
\hline \#ACFemale $*$ POST & & & & & & $\begin{array}{l}0.163^{* * *} \\
(2.819)\end{array}$ \\
\hline Control Variables & Included & Included & Included & Included & Included & Included \\
\hline Constant & $\begin{array}{c}0.393 \\
(0.981)\end{array}$ & $\begin{array}{c}0.403 \\
(1.003)\end{array}$ & $\begin{array}{c}0.393 \\
(0.975)\end{array}$ & $\begin{array}{c}0.298 \\
(0.800)\end{array}$ & $\begin{array}{c}0.312 \\
(1.050)\end{array}$ & $\begin{array}{c}0.364 \\
(1.322)\end{array}$ \\
\hline $\mathrm{n}$ & 10,013 & 10,013 & 10,013 & 10,013 & 10,013 & 10,013 \\
\hline Adjusted $\mathrm{R}^{2}$ & 0.399 & 0.380 & 0.380 & 0.414 & 0.400 & 0.418 \\
\hline
\end{tabular}


members and audit quality may not necessarily increase if the newly appointed female directors are equally, rather than better, qualified than male directors. Further, we acknowledge that we cannot completely rule out an alternative explanation that the ASX CGC guidelines led to a partial reduction in discrimination. ${ }^{24}$

Third, we focus on short-term effects, and it is possible that the effects of gender diversity may change over the long-term as the supply of qualified women directors increases. As identified by a report published by the AICD (2014, 11), "more than half of the appointees (i.e., 58.3 percent) had no past or current ASX 200 non-executive directorships at the time of their appointment. The majority (84.9 percent) had no past ASX 200 directorships." While these appointees may have had little experience at the time of appointment, they will acquire experience with time, suggesting that their performance may improve as their tenures increase. We believe a longitudinal study that examines the learning curves of less experienced gender-diverse audit committees would have scholarly and practical importance.

\section{REFERENCES}

Abbott, L. J., S. Parker, G. Peters, and K. Raghunandan. 2003. The association between audit committee characteristics and audit fees. Auditing: A Journal of Practice \& Theory 22 (2): 17-32. https://doi.org/10.2308/aud.2003.22.2.17

Adams, R. B. 2016. Women on boards: The superheroes of tomorrow? The Leadership Quarterly 27 (3): 371-386. https://doi.org/10. 1016/j.leaqua.2015.11.001

Ahern, K. R., and A. K. Dittmar. 2012. The changing of the boards: The impact on firm valuation of mandated female board representation. The Quarterly Journal of Economics 127 (1): 137-197. https://doi.org/10.1093/qje/qjr049

Aldamen, H., J. Hollindale, and J. L. Ziegelmayer. 2018. Female audit committee members and their influence on audit fees. Accounting \& Finance 58 (1): 57-89. https://doi.org/10.1111/acfi.12248

Australian Institute of Company Directors (AICD). 2014. Female non-executive director appointments to ASX 200 boards. Available at: http://www.companydirectors.com.au/-/media/resources/director-resource-centre/governance-and-director-issues/board-diversity/ board-diversity-pdf/publications/04237-div-asx-200-female-board-appointments-research-report-mar14_web.ashx

Australian Securities \& Investments Commission. 2014. Information Sheet 196. Audit quality: The role of directors and audit committees. Available at: https://download.asic.gov.au/media/1338914/info196-Audit-quality-published-17-March-2014.pdf

Australian Securities Exchange Corporate Governance Council (ASX CGC). 2010. Corporate Governance Principles and Recommendations. 2nd edition. Sydney, Australia: ASX Corporate Governance Council.

Balsam, S., J. Krishnan, and Y. S. Yang. 2003. Auditor industry specialization and earnings quality. Auditing: A Journal of Practice \& Theory 22 (2): 71-97. https://doi.org/10.2308/aud.2003.22.2.71

Baron, R. M., and D. A. Kenny. 1986. The moderator-mediator variable distinction in social psychological research: Conceptual, strategic, and statistical considerations. Journal of Personality and Social Psychology 51 (6): 1173-1182. https://doi.org/10.1037/ 0022-3514.51.6.1173

Barua, A., J. Legoria, and J. S. Moffitt. 2006. Accruals management to achieve earnings benchmark: A comparison of pre-managed profit and loss firms. Journal of Business Finance \& Accounting 33 (5/6): 653-670. https://doi.org/10.1111/j.1468-5957.2006.00017.x

Ben-Amar, W., M. Chang, and P. McIlkenny. 2017. Board gender diversity and corporate response to sustainability initiative: Evidence from the carbon disclosure project. Journal of Business Ethics 142 (2): 369-383. https://doi.org/10.1007/s10551-015-2759-1

Blankley, A. I., D. N. Hurtt, and J. E. MacGregor. 2012. Abnormal audit fees and restatements. Auditing: A Journal of Practice \& Theory 31 (1): 79-96. https://doi.org/10.2308/ajpt-10210

Bøhren, O., and S. Staubo. 2014. Does mandatory gender balance work? Changing organizational form to avoid board upheaval. Journal of Corporate Finance 28: 152-168. https://doi.org/10.1016/j.jcorpfin.2013.12.005

\footnotetext{
${ }^{24}$ Under this view, if discrimination existed before the introduction of ASX CGC 2010, nondiscriminatory firms (i.e., those with female audit committee members) would have higher audit quality than discriminatory firms (i.e., those without female audit committee members) because, in the former case, only extraordinary females are able to break the discrimination barrier and these females improve the committee's performance. Further, if ASX CGC 2010 reduced discrimination, the impact of female audit committee members on audit quality would decline as the women appointees become more similar to male appointees, leading to a weaker relation between audit committee gender diversity and audit quality after gender diversity guidelines were introduced. However, we believe this interpretation is less plausible than our interpretation for the following reasons. First, the impact of women directors who were appointed in the pre-ASX CGC period (i.e., existing women directors) is likely to increase because of better firm-director matching Second, even if women appointed in the post-ASX CGC period are not as capable as women appointed in the pre-ASX CGC period, they will be better matched to firms; therefore, relative to the latter, they can be equally or more effective in their roles. Third, there are benefits from gender diversity that are not solely related to the capabilities of women directors. For example, even if female appointees and male appointees are equally capable, adding women to the audit committee can still have a positive effect on committee performance because women can have a different perspective than men. Fourth, the benefits associated with women on the audit committee increase with the number of women appointed. Thus, while it is possible that postASX CGC women appointees are not as capable as pre-ASX CGC women appointees, the former could be more effective because a critical mass of women is created as more women's appointments are made. All four reasons suggest that, even if the ASX CGC guidelines partially eliminated discrimination, it is not obvious that the relation between women's representation on the audit committee and audit quality would weaken as predicted by the alternative view.
} 
Cahan, S. F., D. C. Jeter, and V. Naiker. 2011. Are all industry specialist auditors the same? Auditing: A Journal of Practice \& Theory 30 (4): 191-222. https://doi.org/10.2308/ajpt-10181

Carcello, J. F., D. R. Hermanson, and Z. Ye. 2011. Corporate governance research in accounting and auditing: Insights, practice implications, and future research directions. Auditing: A Journal of Practice \& Theory 30 (3): 1-31. https://doi.org/10.2308/ajpt10112

Carcello, J. V., D. R. Hermanson, T. L. Neal, and R. A. Riley, Jr. 2002. Board characteristics and audit fees. Contemporary Accounting Research 19 (3): 365-384. https://doi.org/10.1506/CHWK-GMQ0-MLKE-K03V

Chan, A. M. Y., G. Liu, and J. Sun. 2013. Independent audit committee members' board tenure and audit fees. Accounting \& Finance 53 (4): 1129-1147. https://doi.org/10.1111/j.1467-629X.2012.00490.x

Chapple, L., and J. E. Humphrey. 2014. Does board gender diversity have a financial impact? Evidence using stock portfolio performance. Journal of Business Ethics 122 (4): 709-723. https://doi.org/10.1007/s10551-013-1785-0

Chow, C. W., and A. Wong-Boren. 1987. Voluntary financial disclosure by Mexican corporations. The Accounting Review 62 (3): $533-$ 541.

Clifford, P., and R. Evans. 1997. Non-executive directors: A question of independence. Corporate Governance 5 (4): 224-231. https:// doi.org/10.1111/1467-8683.00064

Cohen, D. A., and P. Zarowin. 2010. Accrual-based and real earnings management activities around seasoned equity offerings. Journal of Accounting \& Economics 50 (1): 2-19. https://doi.org/10.1016/j.jacceco.2010.01.002

Cohen, D. A., A. Dey, and T. Z. Lys. 2008. Real and accrual-based earnings management in the pre- and post-Sarbanes-Oxley periods. The Accounting Review 83 (3): 757-787. https://doi.org/10.2308/accr.2008.83.3.757

Dechow, P. M., and I. Dichev. 2002. The quality of accruals and earnings: The role of accrual estimation errors. The Accounting Review 77 (Supplement): 35-59. https://doi.org/10.2308/accr.2002.77.s-1.35

DeFond, M., and J. Zhang. 2014. A review of archival auditing research. Journal of Accounting \& Economics 58 (2/3): 275-326. https:// doi.org/10.1016/j.jacceco.2014.09.002

Dehejia, R. H., and S. Wahba. 2002. Propensity score-matching methods for non-experimental causal studies. The Review of Economics and Statistics 84 (1): 151-161. https://doi.org/10.1162/003465302317331982

Dhaliwal, D. S., O. Z. Li, A. Tsang, and Y. G. Yang. 2011. Voluntary nonfinancial disclosure and the cost of equity capital: The initiation of corporate social responsibility reporting. The Accounting Review 86 (1): 59-100. https://doi.org/10.2308/accr.00000005

Eckbo, B. E., K. Nygaard, and K. S. Thorburn. 2016. Does gender-balancing the board reduce firm value? Available at: https://ideas. repec.org/p/cpr/ceprdp/11176.html

Ferreira, D., E. Ginglinger, M. A. Laguna, and Y. Skalli. 2018. Board quotas and director-firm matching. Available at: https://papers.ssrn. com/sol3/papers.cfm?abstract_id=2992213

Francis, J., A. H. Huang, S. Rajgopal, and A. Y. Zang. 2008. CEO reputation and earnings quality. Contemporary Accounting Research 25 (1): 109-147. https://doi.org/10.1506/car.25.1.4

Gendron, Y., and J. Bedard. 2006. On the constitution of audit committee effectiveness. Accounting, Organizations and Society 31 (3): 211-239. https://doi.org/10.1016/j.aos.2005.03.002

Goodwin-Stewart, J., and P. Kent. 2006. Relation between external audit fees, audit committee characteristics and internal audit. Accounting \& Finance 46 (3): 387-404. https://doi.org/10.1111/j.1467-629X.2006.00174.x

Graham, J. R., C. R. Harvey, and S. Rajgopal. 2005. The economic implications of corporate financial reporting. Journal of Accounting \& Economics 40 (1/3): 3-73. https://doi.org/10.1016/j.jacceco.2005.01.002

Hardies, K., D. Breesch, and D. Branson. 2015. The female audit fee premium. Auditing: A Journal of Practice \& Theory 34 (4): 171195. https://doi.org/10.2308/ajpt-51079

Hay, D. C., W. R. Knechel, and N. Wong. 2006. Audit fees: A meta-analysis of the effect of supply and demand attributes. Contemporary Accounting Research 23 (1): 141-191. https://doi.org/10.1506/4XR4-KT5V-E8CN-91GX

Hinnerich, B. T., and J. Jansson. 2017. Anticipation effects of a board room gender quota law: Evidence from a credible threat in Sweden. Available at: http://www.fmaconferences.org/Norway/Papers/Hinnerich.pdf

Hossain, S., L. Chapple, and G. S. Monroe. 2018. Does auditor gender affect issuing going-concern decisions for financially distressed clients? Accounting \& Finance 58 (4): 1027-1061. https://doi.org/10.1111/acfi.12242

Ittonen, K., J. Miettinen, and S. Vahamaa. 2010. Does female representation on audit committees affect audit fees? Quarterly Journal of Finance and Accounting 49 (3/4): 113-139.

Ittonen, K., E. Vahamaa, and S. Vahamaa. 2013. Female auditors and accruals quality. Accounting Horizons 27 (2): 205-228. https://doi. org/10.2308/acch-50400

Judd, C. M., and D. A. Kenny. 1981. Process analysis: Estimating mediation in treatment evaluations. Evaluation Review 5 (5): $602-619$. https://doi.org/10.1177/0193841X8100500502

Khurana, I. K., and K. K. Raman. 2004. Litigation risk and the financial reporting credibility of Big 4 versus non-Big 4 audits: Evidence from Anglo-American countries. The Accounting Review 79 (2): 473-495. https://doi.org/10.2308/accr.2004.79.2.473

Klein, A. 1998. Firm performance and board committee structure. The Journal of Law \& Economics 41 (1): 275-304. https://doi.org/10. $1086 / 467391$ 
Klein, A. 2002. Audit committee, board of director characteristics, and earnings management. Journal of Accounting \& Economics 33 (3): 375-400. https://doi.org/10.1016/S0165-4101(02)00059-9

Klettner, A., T. Clarke, and M. Boersma. 2016. Strategic and regulatory approaches to increasing women in leadership: Multilevel targets and mandatory quotas as levers for cultural change. Journal of Business Ethics 133 (3): 395-419. https://doi.org/10.1007/s10551014-2069-z

Knechel, W. R., and M. Willekens. 2006. The role of risk management and governance in determining audit demand. Journal of Business Finance \& Accounting 33 (9/10): 1344-1367. https://doi.org/10.1111/j.1468-5957.2006.01238.x

Kogut, B., J. Colomer, and M. Belinky. 2014. Structural equality at the top of the corporation: Mandated quotas for women directors. Strategic Management Journal 35 (6): 891-902. https://doi.org/10.1002/smj.2123

Krishnan, G. V., and G. Visvanathan. 2009. Do auditors price audit committee's expertise? The case of accounting vs. non-accounting financial experts. Journal of Accounting, Auditing \& Finance 24 (1): 115-144. https://doi.org/10.1177/0148558X0902400107

LaLonde, R. 1986. Evaluating the econometric evaluations of training programs with experimental data. The American Economic Review 76 (4): 604-620.

Laux, C., and V. Laux. 2009. Board committees, CEO compensation, and earnings management. The Accounting Review 84 (3): 869 891. https://doi.org/10.2308/accr.2009.84.3.869

Lorsch, J. W., and E. MacIver. 1989. Pawns or Potentates: Reality of America's Corporate Boards. Brighton, MA: Harvard Business Review Press.

Mansi, S. A., W. F. Maxwell, and D. P. Miller. 2004. Does auditor quality and tenure matter to investors? Evidence from the bond market. Journal of Accounting Research 42 (4): 755-793. https://doi.org/10.1111/j.1475-679X.2004.00156.X

McNichols, M. 2002. Discussion of "The quality of accruals and earnings: The role of accrual estimation errors." The Accounting Review 77 (Supplement): 61-69. https://doi.org/10.2308/accr.2002.77.s-1.61

Organisation for Economic Co-operation and Development (OECD). 2004. Corporate governance: A survey of OECD countries: Report number 53391. Available at: https://www.oecd.org/corporate/ca/corporategovernanceprinciples/21755678.pdf

Pucheta-Martínez, M. C., I. Bel-Oms, and G. Olcina-Sempere. 2016. Corporate governance, female directors and quality of financial information. Business Ethics: A European Review 25 (4): 363-385. https://doi.org/10.1111/beer.12123

Read, W., and A. Yezegel. 2016. Auditor tenure and going concern opinions for bankrupt clients: Additional evidence. Auditing: A Journal of Practice \& Theory 35 (1): 163-179. https://doi.org/10.2308/ajpt-51217

Rosenbaum, P. R., and D. B. Rubin. 1983. The central role of the propensity score in observational studies for causal effects. Biometrika 70 (1): 41-55. https://doi.org/10.1093/biomet/70.1.41

Rosenbaum, P. R., and D. B. Rubin. 1985. Constructing a control group using multivariate matched sampling methods that incorporate the propensity score. The American Statistician 39 (1): 33-38. https://doi.org/10.2307/2683903

Roychowdhury, S. 2006. Earnings management through real activities manipulation. Journal of Accounting \& Economics 42 (3): $335-$ 370. https://doi.org/10.1016/j.jacceco.2006.01.002

Rubin, D. B., and N. Thomas. 1996. Matching using estimated propensity scores: Relating theory to practice. Biometrics 52 (1): $249-264$. https://doi.org/10.2307/2533160

Sobel, M. E. 1982. Asymptotic confidence intervals for indirect effects in structural equation models. Sociological Methodology 13: 290312. https://doi.org/10.2307/270723

Srinidhi, B., F. A. Gul, and J. Tsui. 2011. Female directors and earning quality. Contemporary Accounting Research 28 (5): 1610-1644. https://doi.org/10.1111/j.1911-3846.2011.01071.x

Sun, J., G. Liu, and G. Lan. 2011. Does female directorship on independent audit committees constrain earnings management? Journal of Business Ethics 99 (3): 369-382. https://doi.org/10.1007/s10551-010-0657-0

Sun, J., G. Lan, and G. Liu. 2014. Independent audit committee characteristics and real earnings management. Managerial Auditing Journal 29 (2): 153-172. https://doi.org/10.1108/MAJ-05-2013-0865

Terjesen, S., R. V. Aguilera, and R. Lorenz. 2015. Legislating a woman's seat on the board: Institutional factors driving gender quotas for boards of directors. Journal of Business Ethics 128 (2): 233-251. https://doi.org/10.1007/s10551-014-2083-1

Terjesen, S., R. Sealy, and V. Singh. 2009. Women directors on corporate boards: A review and research agenda. Corporate Governance 17 (3): 320-337. https://doi.org/10.1111/j.1467-8683.2009.00742.x

Thiruvadi, S., and H. Huang. 2011. Audit committee gender differences and earnings management. Gender in Management 26 (7): $483-$ 498. https://doi.org/10.1108/17542411111175469

Torchia, M., A. Calabro, and M. Huse. 2011. Women directors on corporate boards: From tokenism to critical mass. Journal of Business Ethics 102 (2): 299-317. https://doi.org/10.1007/s10551-011-0815-z

Trotman, K. T., T. D. Bauer, and K. A. Humphreys. 2015. Group judgment and decision making in auditing: Past and future research. Accounting, Organizations and Society 47: 56-72. https://doi.org/10.1016/j.aos.2015.09.004

U.S. House of Representatives. 2002. Sarbanes-Oxley Act. Public Law No. 107-2004. H.R. 3763. Washington, DC: GPO.

Vafeas, N., and J. F. Waegelein. 2007. The association between audit committees, compensation incentives, and corporate audit fees. Review of Quantitative Finance and Accounting 28 (3): 241-255. https://doi.org/10.1007/s11156-006-0012-9 


\section{APPENDIX A \\ Variable Definitions}

Variable

Ln_AudFee

Chg LnAudFee

$C F O R$

PROD R

$D I S X \_R$

Comp_REM

ChangeREM

$\%$ ACFemale

DumACFemale

\#ACFemale

POST

Add Fem

Fem_Replace_Male

ChangeFem

\%ACInd

\%ACFin

ACMul

ACMeet

ACTenure

ACSize

Duality

BSize

BoDInd

Ln_NAS

Big4

Aud_Gender

Aud_Ind-Specialist

Aud Tenure

Ln TA

$R O A$

$M B$

Leverage

Inv_Rec

$\mathrm{Sub}$

Bus Seg

Geo_Seg

Loss

CFO

Rev

$\mathrm{CFO} \mathrm{Vol}$

Rev $\bar{V}$ ol
Definition

Natural logarithm of auditor's fee of firm $i$ for year $t$.

Year-to-year change in the logarithm of audit fees of firm $i$ for year $t$

Level of abnormal cash flows from operations of firm $i$ for year $t$.

Level of abnormal production costs, where production costs are defined as the sum of cost of goods sold and the change in inventories of firm $i$ for year $t$.

Level of abnormal discretionary expenses, where discretionary expenses are the sum of advertising expenses, $\mathrm{R} \& \mathrm{D}$ expenses, and SGA expenses of firm $i$ for year $t$.

Sum of the standardized three real earnings management proxies (i.e., $P R O D \_R, D I S X \_R$, and $C F O \_R$ ) of firm $i$ for year $t$.

Year-to-year change in the sum of the standardized three real earnings management proxies (i.e., $P R O D R$, $D I S X \_R$, and $C F O \_R$ ) of firm $i$ for year $t$.

Percentage of female audit committee members of firm $i$ for year $t$.

Indicator variable equal to 1 if there is a female member on the audit committee of firm $i$ for year $t$, otherwise 0.

Total number of female audit committee members of firm $i$ for year $t$.

Indicator variable equal to 1 for firm-year observations after 2010, otherwise 0 .

Indicator variable equal to 1 if firm $i$ has added at least one female member to the audit committee members during year $t$ when there is already an existing female member on the audit committee, otherwise 0 .

Indicator variable equal to 1 if firm $i$ replaces a male audit committee member with a female audit committee member during year $t$, otherwise 0 .

Dummy variable equals to 1 if there is a year-to-year change in the number of female audit committee members of firm $i$ for year $t$, otherwise 0 .

Percentage of independent audit committee members of firm $i$ for year $t$.

Percentage of financially expert audit committee members of firm $i$ for year $t$.

Average number of multiple directorships held by audit committee members of firm $i$ for year $t$.

Total number of audit committee meetings held for firm $i$ for year $t$.

Average tenure of audit committee members of firm $i$ for year $t$.

Total number of members serving on the audit committee of firm $i$ for year $t$.

Indicator variable equal to 1 if the CEO of firm $i$ for year $t$ is also the chairman of the board, otherwise 0 .

Total number of members serving on the board of directors of firm $i$ for year $t$.

Percentage of independent board members of firm $i$ for year $t$.

Natural logarithm of nonaudit service fees of firm $i$ for year $t$.

Indicator variable equal to 1 if the auditor of firm $i$ for year $t$ belongs to the Big 4 , otherwise 0 .

Indicator variable equal to 1 if firm $i$ has appointed a female auditor for year $t$, otherwise 0 .

Indicator variable equal to 1 if an auditor has a 30 percent market share in an industry for year $t$, consistent with Cahan et al. (2011), otherwise 0.

Number of consecutive years an incumbent audit firm has audited firm $i$ at the end of year $t$.

Natural logarithm of the total assets of firm $i$ for year $t$.

Net profit after tax divided by total assets of firm $i$ for year $t$.

Market value of equity divided by book value of equity of firm $i$ for year $t$.

Total liabilities divided by total assets of firm $i$ for year $t$.

Inventory plus accounts receivables divided by total assets of firm $i$ for year $t$.

Total number of subsidiaries of firm $i$ for year $t$.

Total number of business segments of firm $i$ for year $t$.

Total number of geographical segments of firm $i$ for year $t$.

Indicator variable equal to 1 if firm $i$ for year $t$ reports a loss, otherwise 0 .

Cash flow from operations of firm $i$ for year $t$

Total revenue of firm $i$ for year $t$

Standard deviation (over five years) of cash flow from operations of firm $i$ for year $t$.

Standard deviation (over five years) of total revenue of firm $i$ for year $t$. 
Queries for ajpt-39-01-05

1. Author: re footnote 5: For the citation "Ferreira et al. $(2018,29)$ " the page number used in the citation no longer corresponds to the page number of the article and has been deleted. Copyeditor

2. Author: The first initials for same-last-name authors in a citation have been inserted at the first mention of that citation due to a change in AAA standard style. Review carefully. Copyeditor

3. Author: re footnote 9: For the sentence beginning "Results suggest that there is no significant association ..." the phrase "firms are not dissimilar to" is awkward. Please review and revise as warranted. Copyeditor

4. Author: All tables (including appendices) have been formatted to conform to AAA style guidelines and XML formatting constraints. Please review carefully. Copyeditor

5. Author: To conform to standard AAA style format, all variables have been made consistent with the first mention of the variable throughout the equations, text, and tables. Please check all uses of variables to confirm that the formatting (and spelling/format) is consistent throughout the article and tables. Copyeditor

6. Author: re footnote 15: For the sentence beginning "Consistent with our expectations ..." I slightly modified the parenthetical wording for clarity. Please confirm that the intended meaning of the statement has not been changed. Copyeditor

7. Author: re Table 3: The single asterisk $(*)$ in the table notes is not annotated in the table data. OK? Copyeditor

8. Author: re Table 4: The single asterisk $(*)$ in the table notes is not annotated in the table data. OK? Copyeditor

9. Author: re Table 5: The single asterisk $(*)$ in the table notes is not annotated in the table data. OK? Copyeditor

10. Author: re Tables 5-9 table notes: The parentheses for Panel B dependent variable statements have been removed for clarity and grammatical correctness. Please approve as is, or mark to revise as preferred. Copyeditor

11. Author: For the sentence beginning "However, notably, the combined coefficient ...": The coefficient for \%ACFemale * POST is -0.605 . Is the parenthetical math correct as shown, or should the math perhaps be $(1.117-(-0.605))$ ? Please review and revise as warranted. Copyeditor

12. Author: re Table 6: The single asterisk $\left(^{*}\right)$ in the table notes is not annotated in the table data. OK? Copyeditor

13. Author re: Table 8, Panels A and B: We are unable to accommodate two sets of data in the same cell. The data have been separated into an additional column. Please approve and add column headings if desired. Thank you. Copyeditor

14. Author: For the sentence beginning "Thus, we shed light ..." the phrase "role of board, i.e., monitoring financial reporting quality" is grammatically incorrect. Please review and revise as warranted. Copyeditor

15. Author: Some reference entries and corresponding in-text citations have been revised or updated based on the information provided by CrossRef and appropriate web searches. Review the "References" section carefully and provide approval (with an "OK" to "Confirmed" response to this query). Please note that there may be other citation- or reference-specific queries that need your attention. Thank you. Copyeditor 